\title{
Relationship between 'Language and Emergent Literacy' before School Age and Literacy Performance Levels for First and Second Graders: Data Mining Decision Tree Model Analysis
}

\author{
Eun Ju Lee \\ The Special Education Research Institute (SERI), Ewha Womans University, Seoul, Korea
}

Correspondence: Eun Ju Lee, PhD

The Special Education Research Institute (SERI), Ewha Womans University, 52 Ewhayeodae-gil, Seodaemun-gu, Seoul 03760, Korea

Tel: +82-10-7335-1953

Fax: +82-2-3277-2679

E-mail: imfedra@naver.com

Received: July 5, 2021

Revised: July 27, 2021

Accepted: July 27, 2021

This work was supported by the Ministry of Education of the Republic of Korea and the National Research Foundation of Korea (No. NRF2020S1A5B5A16082517).

\begin{abstract}
Objectives: The purpose of this study was to identify factors (language and emergent literacy before school age) affecting Hangul reading and writing performance level in the first and second grades of elementary school. Methods: A decision tree analysis was conducted to examine the Panel Study on Korean Children (PSKC) of the Korea Institute of Child Care and Education (KICCE) on the 7th (kindergarten, 6 years old), 8th (first grade, 7 years old), and 9th data (second grade, 8 years old). Results: Reading and writing performance levels of 1 st and 2 nd grade children were related to reading first grade books independently with comprehension, reading most words correctly and answering questions about what was read, making predictions while reading, and retelling story after reading. Children with reading levels within the top 20 percent frequently chose reading \& writing-related activities, frequently looked at or read books for pleasure or to gain information, looked for books related to a personal interest or class topic, listened with interest and concentration to stories read aloud, made rhyme words, followed directions that include a series of actions, and were able to write relatively simple words such as 'mom' and 'dad'. Conclusion: The findings are expected to serve as a basis for understanding what areas of literacy education should be given to children with low reading and writing performance.
\end{abstract}

Keywords: PSKC, Reading, Writing, Emergent literacy, Decision tree analysis
읽기와 쓰기는 학업성취에 있어 가장 기본이 되는 필수 요소이 다. 즉, 초등학교 저학년 시기의 읽기 및 쓰기 교육은 아동이 활자 정보를 읽고 쓰는 방법을 습득하여 읽기 및 쓰기와 관련된 학업과 생활에서 어려움 없이 적응할 수 있도록 하는 것이다. 그리고 이러 한 읽기와 쓰기 능력은 본격적인 읽기 ·쓰기 문해 교육이 시작되는 초등학교 입학 이전 시기부터, 연령에 맞게 발달해야 하는 제반 능 력이 요구된다(Jung, 2019; Kim, 2017).

한글을 읽고 이해하기 위해서 우선적으로 아동은 한글을 해독 할 수 있어야 하며, 해독한 낱말과 문장에 대한 언어 이해력이 있어 야글을 이해할 수 있다. 즉, 읽기 발달의 궁극적인 목적인 읽기 이해 를 위해서는 문자를 해독하는 낱말 읽기능력과 언어 이해력 모두를
갖추고 있어야 한다. '읽기 단순관점 모델(simple view of reading; Catts, Adlof, \& Weismer, 2006; Gough, Hoover, \& Perterson, 1996)' 에서는 읽기를 '인쇄물을 소리로 전환하는 단어 재인(word recognition)' 처리 과정과 '단어와 문장, 담화 등을 해석하는 언어 이해 (linguistic comprehension)' 능력을 포괄하는 처리 과정으로 보고 있다. 이러한 단어 재인과 언어 이해 능력은 초등학교에 입학하면 서 명시적 교육을 통해서만 습득되는 것은 아니다. 현재 명시적 읽 기 · 쓰기 교육이 진행되기 이전인 유치원 시기부터, 아이들에게는 읽기와 쓰기를 위한 기본적인 교육이 진행되고 있다(Kim, 2020).

교육부 2019년 개정 유치원 누리과정(만 3-5세)에서는 1일 4-5시 간을 기준으로 '신체운동 . 건강, 의사소통, 사회관계, 예술경험, 자 
연탐구'의 5 개 영역을 중심으로 한 교육안이 마련되어 있다. 누리과 정 5 개 영역 교육안 중, 의사소통 영역은 '연령에 적합한 듣기와 말 하기, 읽기와 쓰기에 관심 갖기, 책과 이야기 즐기기'로 구분되어 있 으며, 읽기와 쓰기에 관심가지기에 대한 세부 목표로 '말과 글의 관 계에 관심을 가진다.' '주변의 상징, 글자 등의 읽기에 관심을 가진 다.', '자신의 생각을 글자와 비슷한 형태로 표현한다.와 같은 교육 목표가 정해져 있다(Ministry of Education, 2019).

하지만 누리과정을 교육하는 유아 교사들은 유아기 읽기 · 쓰기 에 대해 어떠한 내용과 방법으로 가르쳐야 하는지에 대한 고민이 지속되고 있다. 현재는 글자-소리 관계 원리를 교수하는 발음 중심 교수법(phonics instruction), 통글자 읽기 중심의 총체적 언어 접근 법(whole language approach), 그리고 두 교수법의 절충안인 균형 적 언어 접근법(balanced language approach) 세 가지 모두 혼용되 어 교수 되고 있는 실정이다(Kim \& Kim, 2016). 여러 선행연구들 에 의하면 유치원 교사들은 발음 중심 교수법보다는 총체적 언어 접근법에 근거한 문자 교육을 선호하는 것으로 나타났다(Jang, 2014; Kim, 2005; Lee, 2005; Park, Kim, \& Park, 2013; Park, Lee, \& Jeon, 2012). 총체적 언어 접근법의 기본적인 논거는 읽기는 체계적 인 지도보다는 자연스럽게 통글자 읽기 노출 빈도의 증가에 의해 발달한다고 보는 것이다. 하지만 음운인식 역량이 낮은 아동에게 통글자 교수법은 읽기 발달에 큰 어려움을 야기할 수 있다. 즉, 글 자-소리 관계의 원리를 가르치기보다는 암기식으로 글자와 의미를 연결하는 교수에 의해 다양한 어휘에 대한 노출과 기억이 요구되는 읽기 교수는 읽기문제 위험 요소를 보이는 아동들에게는 더욱 치 명적인 읽기문제를 야기하는 교수법일 수 있다(Kim, 2017; Lim \& Son, 2018).

전 세계 수많은 언어는 표음문자를 사용하고 있다. 영어도 표음 문자에 속하는 것으로 로마자 알파벳 부호를 문자로 사용하고 있 으며, 이들 알파벳 부호는 의미로 구분되는 것이 아니라 소리로 구 분된다. 그리고 한글 또한 표음문자에 속하는 문자로서, 한글은 개 별 자음과 모음의 글자가 나타내는 음가를 알고 조합하는 원리를 배워 읽기를 배우는 전형적인 표음문자의 속성을 나타내고 있다. 문해교육은 사용 언어와 문자 특성에 맞는 교육안이 적용되어야 한다. 교사의 선호에 따라 교육방법이 정해지기 보다는 한글이라 는 표음문자 특성에 적합한 한글 자모 글자 소리 대응 규칙을 적용 하는 교수안이 적용되어야 한다. 하지만 현재 유아 교육현장에서는 발음 중심의 파닉스 교수법에 대한 교사들의 이해와 적용방법에 대한 지식적인 제한 문제가 있다(Choi, 2007; Lee, 2004; Lee, 2008).

유치원 시기의 문해능력 발달은 학습 준비도의 개념을 포함하고 있다. 그래서 이들 학령전 아동에 대해 읽기를 학습할 수 있는 준비
가 되어 '있다/아니다' 같은 이분적인 분류가 일반적으로 받아들여 져 왔다(Lonigan, Burgess, \& Anthony, 2000). 그리고 많은 교육자 들은 아동이 인지적으로 학습에 대한 준비가 가능한 성숙 정도가 되어 있을 때까지는 명시적인 읽기와쓰기 학습을 진행해서는 안 된 다는 견해를 가지고 있었다. 하지만 근래 이 개념은 명시적인 읽기 쓰기 교육 이전인 유치원 시기에서부터 대부분의 읽기 · 쓰기와 언어 능력이 발달하고 있다는 개념으로 변화하였으며, 학령전 시기 발현 문해능력(emergent literacy) 발달에 대해 중요하게 인식하고 있다.

발현 문해능력에 대한 관점은 이전 읽기 준비도의 두 가지 개념 과는 다른 출발점을 가진다. 첫째, 발현 문해능력 관점에서는 읽기 전 단계와 읽기 단계 사이의 명확한 경계를 지정하지 않는다. 즉, 읽 고 쓰는 능력은 아동의 삶에서 일찍부터 시작되며, 중요한 읽고 쓰 는 능력 성취가 공식적인 교육 이전에 나타난다고 보고 있다(van Kleeck, 1990; Whitehurst \& Lonigan, 1998). 두 번째, 읽기 · 쓰기 및 구화 언어(듣기, 말하기)가 비공식적인 사회적 맥락에서 상호 연 계된 방식으로 발전한다는 믿음이다(Whitehurst \& Lonigan, 1998). 즉, 아이들은 문해 사회화를 통해 주변의 세상에 대해 배우면서, 인 쇄 문자가 어떻게 작용하는지에 대한 지식을 얻는다고 보고 있다 (Cabell et al., 2015).

발현 문해능력 단계는 초기 문해능력이나초기 읽기능력과는 다 른 개념이다. 발현 문해능력 발달 단계 아동들은 읽기를 시작하는 것이 아니라 읽기가 발달하는 초기 읽기능력 발달 단계가 나타나 고 있는 대상자들이다. 그러므로 발현 문해능력 단계의 아동들은 단어를 해독하지 못하며, 단지 시각적인 단서를 바탕으로 환경적 지문을 식별하면서 시각적 신호를 읽고 있다(Ehri, 2005; Ehri \& Wilce, 1985). 결과적으로, 발현 문해능력 단계의 아동들에 대한 문 해교육은 읽기에 대한 방법을 가르치는 것이 아니라 오히려, 공식적 인 독해 교육으로의 전환을 용이하게 할 소리, 인쇄물, 구어 언어에 대한 이해의 기초가 발달하도록 돕는 것이다(Cabell et al., 2015).

이렇듯, 발현 문해능력은 공식적인 읽기능력의 발달 이전에 보이 는 읽기 · 쓰기에 대한 기술, 태도, 그리고 환경을 포함하는 개념이 다. 즉, 태어나면서부터 만 5 세 아동시기까지의 듣기와 말하기, 창안 적 쓰기 및 읽기 등을 모두 포함하는 것으로 초등학교 입학 후 진행 되는 공식적인 읽기·쓰기 교육에 대한 선행 기술이다(Je, 2014).

'미국 국립 조기 문해능력 패널연구(The National Early Literacy Panel; NELP, 2004)'는 초기 문해능력에 대한 234개 연구들에 대한 메타분석을 실시하였다. 그 결과 유치원 시기 발현 문해능력 중 아 동기 후반의 읽기와 쓰기 문해능력을 예측하는 강력한 요인들을 몇 가지 확인할 수 있었다. NELP (2004)를 통해서 확인된 요인은 음운인식(Phonological awareness), 인쇄물 인식(Print awareness), 
문자 알파벳 지식(Alphabet knowledge), 발현 쓰기능력(Emergent writing), 구어(듣기, 말하기)능력(Oral language), 추론 언어능력 (Inferential language), 어휘력(Vocabulary) 등 7가지로 구분할 수 있었다. 그리고 이러한 7가지 문해 예측인자들은 크게 해독관련 기 술(code-related skills)과 듣기와 말하기 구어언어 기술(oral language skills) 두 가지 영역으로 구분되며 이들 영역들은 상호 관련되어 있 다고 한다(Lonigan, 2006; Storch \& Whitehurst, 2002; Whitehurst \& Lonigan, 1998; Won, Won, Jang, Lee, \& Pae, 2020). 해독관련 기 술(code-related skills)은 문자와 음소를 구분하여 읽기 기술을 배 우는 것으로 음운인식, 인쇄물 인식, 문자 알파벳 지식, 발현 쓰기 등이 포함되며, 구어언어 기술(oral language skills)에는 구어능력 과 추론 언어능력, 어휘력 등이 포함된다.

해독관련 기술(code-related skills)과 같은 발현 문해능력은 아 동기의 초기 단어 해독능력과 강력한 관련성이 있는 것으로 나타 났다(NELP, 2004). 그리고 구어언어 기술(oral language skills)은 읽기 유창성 단계 아동의 읽기 이해능력을 예측하는 강력한 요인 으로 작용하고 있었다(NELP, 2004). 학령전기에는 학령기와는 다 르게 이런 해독관련 기술(code-related skills)과 구어언어 기술(oral language skills)이 서로 더욱 깊이 관련되어 있으며, 이러한 두 가지 기술은 ‘발현 문해능력’으로 구분된다(Storch \& Whitehurst, 2002).

학령전기 발현 문해능력이 이후 학령기 아동의 문해발달에 영 향을 미친다는 NELP (2004) 연구 및 이후 다양한 연구에서, 유치 원 시기의 발현 문해능력은 이후 학령기 아동 및 청소년의 읽기 성 취의 기초가 되는 것으로 알려져 있다(Lonigan, Schatschneider, Westberg, \& The National Early Literacy Panel [NELP], 2008; Lonigan, Wagner, \& Torgesen, 2007; Pence, 2007; Whitehurst \& Lonigan, 1998). 그러므로 발현 문해능력과 언어 이해 두 가지 요소가 함께 발달하는 것이 학령기 아동의 읽기와 쓰기 성취에 있어 중요 하다(Lovelace \& Stewart, 2007; Storch \& Whitehurst, 2002). 또한 학령 초기의 읽기능력은 고등학교 시기의 읽기능력과도 관련이 있 었다고 한다(Cunningham \& Stanovich, 1997; Yang, Kim, \& Ra, 2017). 그러므로 유치원 시기에 읽기와 쓰기 기술에 대한 흥미를 유 도하여 교육하는 것은, 아동이 초등학교를 입학하여 생활하는 학 령 초기, 그리고 이후 학령기 아동이 청소년이 될 때까지 계속해서 읽기 성취에 있어 중요한 역할을 하고 있다.

위의 연구들을 종합하여 보았을 때, 유치원 시기의 발현 문해능 력과 언어 이해능력의 다양한 구성 요소들은 학령기 이후의 읽기 와 쓰기 문해발달에 유의미한 영향을 미치고 있음을 알 수 있었다. 하지만 현재 2019년 개정된 누리과정의 교육 목표만으로 유아 교 사들이 문해교육을 수행하는 것에는 어려움이 있는 것으로 보인
다. 이에 이번 연구의 목적은 학령기 아동의 읽기와 쓰기 수행능력 에 중요한 요소로 작용하는 유치원 시기의 발현 문해능력과 언어 이해능력의 다양한 구성 요소 중, 한국어와 한글을 배우는 아이들 에게 가장 의미 있는 발현 문해능력과 언어능력 요인은 무엇인지를 분석하여, 언어치료 및 유아교육, 그리고 문해관련 전문가들의 초 기 문해 교육 목표 설정에 도움이 되고자 한다.

이에 본 연구는 초등학교 1-2학년 시기에 한글 읽기와 쓰기 능력 성취 수준에 영향을 미치는 학령전 발현 문해능력과 언어 이해 요 소들을 살펴보고, 학령전 아동 교육 현장에서 어떠한 언어 및 발현 문해능력에 명시적인 교수가 요구되는지를 살펴보았다. 즉, 한국어 를 사용하면서 한글을 배우기 시작하는 만 6세 유치원 아동들의 언어 및 발현 문해능력을 평가하여, 이후 이들 대상자들이 초등학 교 1-2학년 시기에 한글 읽기와 쓰기 수행능력에 있어서는 어떠한 수준을 보이는지를 평가하여 분석하여 보았다. 분석 데이터는 한 국육아정책연구소(Korea Institute of Child Care and Education, KICCE) 한국아동패널(Panel Study on Korean Children, PSKC)의 2014년 7차 데이터(유치원생, 6세)와 2015년 8차(초등학교 1학년, 7 세), 2016년 9차(초등학교 2학년, 8 세) 데이터를 이용하였다. 구체적 인 연구문제는 다음과 같다.

연구문제 1. 초등학교 1,2 학년의 읽기 및 쓰기 수행은 학령전(6세) 언어 및 발현 문해능력과 어느 정도 상관관계가 있는가?

연구문제 1. 초등학교 1 학년의 읽기능력을 가장 잘 예측하는 학령 전 6세 아동의 언어 및 발현 문해능력 변수는 무엇인가?

연구문제 2. 초등학교 1학년의 쓰기능력을 가장 잘 예측하는 학령 전 6세 아동의 언어 및 발현 문해능력 변수는 무엇인가?

연구문제 3. 초등학교 2학년의 읽기능력을 가장 잘 예측하는 학령 전 6세 아동의 언어 및 발현 문해능력 변수는 무엇인가?

연구문제 4. 초등학교 2학년의 쓰기능력을 가장 잘 예측하는 학령 전 6세 아동의 언어 및 발현 문해능력 변수는 무엇인가?

\section{연구방법}

\section{연구대상}

한국육아정책연구소(KICCE) 한국아동패널(PSKC)은 2008년 4 월에서 7월 사이에 출생한 신생아 2,150가구를 조사 모집단으로 하 고 있다. 그리고 이들 대상자들이 성인기에 접어드는 2027년까지 총 20 년간 전반적인 아동 발달 특성과 부모 특성, 가정과 교육 및 지 역사회 환경 특성 자료를 수집하고 있다.

이번 연구에서는 2014년 7차년도(학령전, 6살), 2015년 8차년도 (초등학교 1학년, 7살)와 2016년 9차년도(초등학교 2학년, 8살)의 3 
년간의 조사자료를 분석한 것이다. 2008년 1차년에 원표본 2,150 명 (100.0\%) 대상자들에 비하여, 7차년 조사는 1,203명(55.95\%), 8차 년 조사는 1,031 명(47.95\%), 9차년 조사는 930명(43.26\%)이 조사에 참여하였다. 패널 대상자들의 남/여 비율은 2014년에는 남 아동이 622 명(51.70\%), 여 아동이 581명(48.30\%)이었으며, 2015년에는 남 아동이 524 명(50.82\%), 여 아동이 507명(49.18\%)이었다. 그리고 2016년에는 남 아동이 477명(51.29\%), 여 아동이 453명(48.71\%)이 었으며, 모든 기간에 남/여 비율은 유사한 수준이었다.

패널 대상자들의 거주지역은 17 개 시/도(서울특별시, 부산광역 시, 대구광역시, 인천광역시, 광주광역시, 대전광역시, 울산광역시, 경기도, 강원도, 충청북도, 충청남도, 경상북도, 경상남도, 전라북 도, 전라남도, 제주도, 세종시)로 구분하여 조사되었는데, 이러한 결 과는 교육부에서 2019년 8월에 발표한 2019년 교육기본통계표(The Korean Ministry of Education, 2019)의 전국 지역별 초등학교 학생 수의 비율과 유사하였다. 특히 경기도, 서울, 경상도 순으로 대상자 아동의 수가 많은 것에 있어 일치된 결과를 보였으며 지역분포에 있 어 전국 지역별 초등학생 수 비율에 유사한 수준이었다(Lee \& Oh, 2019). 자세한 대상자 구성 정보는 Table 1에 제시하였다.

\section{측정도구}

언어 및 발현 문해능력(Academic Skills, Language and

\section{Emergent Literacy)}

미국 '국립아동보건 인적개발원(National Institute of Child Health and Human Development, NICHD)'의 2단계 연구인 ‘아동 및 청소 년 발달 연구(Study of Early Child Care and Youth Development, SECCYD)'는 54개월에서 초등학교 1학년 시기의 아동을 대상으로 다양한 연구가 진행되었다. 이 시기는 읽기와 쓰기를 학습하는 시기 로, NICHD SECCYD는 아동의 발현 문해능력을 측정하기 위해 사 용된 '학업능력(academic skills)' 검사 문항을 고안하였다. 그리고 한국아동패널 연구진은 학업능력 검사 문항 중 '언어 및 문해능력 (language and literacy)' 문항을 한국어로 번역하여, 국내 아동을 대 상으로 예비조사 실시 후 13 개 문항을 선정하고, 한국어 특성을 반 영한 쓰기 관련 1문항을 추가하였다. 그리고 이러한 검사 문항은 종 단연구 대상자들이 소속되어 있는 육아지원기관의 담임교사가 web 설문지를 통해 응답하도록 하였다. 이번 연구는 이러한 14 개 문 항에 대해 ‘언어 및 발현 문해능력’ 평가로 분류하여 분석하였다.

문항에 대한 점수화는 '아직 하지 않음(1점), 하기 시작함(2점), 어 느 정도 해냄(3점), 잘하는 편임(4점), 능숙함(5점)'과 같은 5점 리커 트 척도[5-point Likert-type scale; Not yet(1) - Beginning(2) - In Progress(3) - Intermediate(4) - Proficient(5)] 를 사용하였다(Table 2).
Table 1. Participants' information

\begin{tabular}{|c|c|c|c|}
\hline Characteristic & 2014 (7th) & 2015 (8th) & 2016 (9th) \\
\hline \multicolumn{4}{|l|}{$\mathrm{N}$} \\
\hline Valid & $1,203(55.95)$ & $1,031(47.95)$ & 930 (43.26) \\
\hline Missing & $947(44.04)$ & $1,119(52.05)$ & $1,220(56.74)$ \\
\hline All & $2,150(100.0)$ & $2,150(100.0)$ & $2,150(100.0)$ \\
\hline Grade & K & $1 \mathrm{st}$ & 2nd \\
\hline \multicolumn{4}{|l|}{ Gender } \\
\hline Male & $622(51.70)$ & $524(50.82)$ & $477(51.29)$ \\
\hline Female & $581(48.30)$ & $507(49.18)$ & $453(48.71)$ \\
\hline All & $1,203(100.0)$ & $1,031(100.0)$ & $930(100.0)$ \\
\hline Age (yr) & 6 & 7 & 8 \\
\hline \multicolumn{4}{|c|}{ Residential area (17 different cities/regions) } \\
\hline Seoul & $154(12.80)$ & $99(9.71)$ & $87(9.51)$ \\
\hline Busan & $70(5.82)$ & $52(5.10)$ & $61(6.67)$ \\
\hline Daegu & $101(8.40)$ & $79(7.75)$ & $73(7.98)$ \\
\hline Incheon & $38(3.16)$ & $28(2.75)$ & $26(2.84)$ \\
\hline Gwangju & $41(3.41)$ & $43(4.22)$ & $33(3.61)$ \\
\hline Daejeon & $55(4.57)$ & $54(5.29)$ & $54(5.90)$ \\
\hline Ulsan & $67(5.60)$ & $68(6.67)$ & $62(6.78)$ \\
\hline Gyeonggi Province & $318(26.43)$ & 269 (26.37) & $208(22.73)$ \\
\hline Gangwon Province & $10(0.83)$ & $11(1.08)$ & $11(1.20)$ \\
\hline Chungcheongbuk-do & $34(2.83)$ & $27(2.65)$ & $24(2.62)$ \\
\hline Chungcheongnam-do & $71(5.90)$ & 68 (6.67) & $60(6.56)$ \\
\hline Gyeongsangbuk-do & $57(4.74)$ & $51(5.00)$ & 51 (5.57) \\
\hline Gyeongsangnam-do & $56(4.66)$ & $53(5.20)$ & $52(5.68)$ \\
\hline Jeolabuk-do & $41(3.41)$ & 40 (3.92) & $33(3.61)$ \\
\hline Jeolanam-do & $80(6.65)$ & $70(6.86)$ & $71(7.76)$ \\
\hline Jeju-do & $3(0.25)$ & $2(0.20)$ & $3(0.33)$ \\
\hline Sejong-si & $7(0.58)$ & $6(0.59)$ & $6(0.66)$ \\
\hline
\end{tabular}

Values are expressed as number (percentage).

$\mathrm{K}=$ Kindergarten; $1 \mathrm{st}=$ First grade in elementary school; $2 \mathrm{nd}=$ Second grade in elementary school.

읽기 \& 쓰기 학업 수행능력(Academic Performance, Reading \& Writing)

KICCE 한국아동패널(PSKC)에서는 대상자들이 초등학교 입학 후, 매년 담임교사가 국어와 수학과 같은 기초과목과 과학, 사회, 예 체능 교과과목에 대한 대상자들의 학업 수행능력을 평가하도록 하였다. 이중 이번 연구에서는 국어과목 읽기와 쓰기에 대한 평가 문항 결과만을 선택하여 분석에 활용하였다.

과목 문항에 대한 점수화는 ‘하위 $20 \%$ 이내(1점)와 상위 $20 \%$ 이 내(5점)'와 같은 5점 리커트 척도[5-point Likert-type scale; Within the bottom $20 \%(1)$ - Bottom 21 to $40 \%(2)$ - Medium 50\% or less(3) Top 21 to 40\%(4) - Top 20\%(5)]를 사용하였다(Table 3). 
Table 2. Items and scale of language and emergent literacy

\begin{tabular}{|c|c|c|c|c|c|c|}
\hline \multirow{2}{*}{ No. } & \multirow{2}{*}{ Items } & \multicolumn{5}{|c|}{ Scale } \\
\hline & & NY & B & $\mathbb{P}$ & Int & $P$ \\
\hline 1 & Follows directions that include a series of actions & 1 & 2 & 3 & 4 & 5 \\
\hline 2 & Use rather complex sentence structures & 1 & 2 & 3 & 4 & 5 \\
\hline 3 & Understands and interpret a story or other text read to him/her & 1 & 2 & 3 & 4 & 5 \\
\hline 4 & Reads all the consonants and vowels of Hangul easily and quickly & 1 & 2 & 3 & 4 & 5 \\
\hline 5 & Makes rhyme word & 1 & 2 & 3 & 4 & 5 \\
\hline 6 & Frequently and eagerly chooses reading related activities & 1 & 2 & 3 & 4 & 5 \\
\hline 7 & Can predict what story will follow by looking at clues or pictures in the plot. & 1 & 2 & 3 & 4 & 5 \\
\hline 8 & Reads first grade books independently with comprehension & 1 & 2 & 3 & 4 & 5 \\
\hline 9 & Indicates the initial write behavior. & 1 & 2 & 3 & 4 & 5 \\
\hline 10 & Write relatively simple words such as 'mom', 'dad', 'you' and 'hello'. & 1 & 2 & 3 & 4 & 5 \\
\hline 11 & Remember and write relatively complex words Such as 'Korea', 'Like' and 'Smile' & 1 & 2 & 3 & 4 & 5 \\
\hline 12 & Demonstrates an understanding of some of the conventions of print & 1 & 2 & 3 & 4 & 5 \\
\hline 13 & Frequently and eagerly chooses writing related activities & 1 & 2 & 3 & 4 & 5 \\
\hline 14 & Uses the computer for a variety of purposes & 1 & 2 & 3 & 4 & 5 \\
\hline
\end{tabular}

Source: KICCE (Korea Institute of Child Care and Education, https://kicce.re.kr/panel); NICHD Study of Early Child Care and Youth Development: Phase II, 1995-1999 [United States] (ICPSR 21941) (http://www.icpsr.umich.edu/icpsrweb/ICPSR/studies/21941).

$\mathrm{B}=$ Beginning; $\mathrm{IP}=$ In Progress; Int= Intermediate; $\mathrm{NY}=$ Not Yet; $\mathrm{P}=$ Proficient.

Table 3. Items and scale of a fluent use of the multicultural adolescents' Korean and foreign language

\begin{tabular}{lccccc}
\hline Items & B & B 21 to & M & T21 to & T \\
& $20 \% \geq$ & $40 \%$ & $50 \%$ & $40 \%$ & $20 \% \leq$ \\
\hline How good is your reading ability? & 1 & 2 & 3 & 4 & 5 \\
How good is your writing ability? & 1 & 2 & 3 & 4 & 5 \\
\hline
\end{tabular}

Source: KICCE (Korea Institute of Child Care and Education, https://kicce.re.kr/panel). B 20\% $\geq=$ Within the bottom 20\%; B 21 to 40\% = Bottom 21 to 40\%; M 50\% =Medium 50\% or less; T 21 to 40\% = Top 21 to 40\%; T 20\% $\leq=$ Top 20\%.

\section{연구절차}

PSKC는 전문조사원에 의한 설문지 면접조사와 인터넷을 통한 설문지조사 방법이 모두 이용되었으며, 본 연구에 이용된 데이터는 유치원 및 초등학교 담임교사를 대상으로 진행된 인터넷 설문조사 형식이었다. 그리고 모든 패널은 6-12월에 조사를 실시하여 데이터 를 수집하였다.

이번 연구는 한국아동패널(PSKC) 대상자들이 초등학교에 입학 하기 전 6세 시기에 담임교사가 평가한 대상자들의 언어 및 발현 문 해능력 문항 평가가 대상자들의 초등학교 1 학년과 2 학년 시기에 담 임교사가 평가한 읽기와 쓰기 수행 능력과 어떠한 관련을 보이는지 를 분석하였다. 그러므로 언어 및 발현 문해능력은 KICCE PSKC 데이터 중 W7 (2014년, 6세)에 조사된 '학업능력' 평가지의 '언어 및 문해능력' 14 개 문항 평가 결과를 이용하였으며, 읽기와 쓰기 수행 능력은 W8 (2015년, 7세, 초등학교 1학년)과 W9 (2016년, 8세, 초등 학교 2학년)에 조사된 '학업 수행능력' 평가 문항에서 '읽기와 쓰기'
2개 문항 결과만을 추출하여 분석에 활용하였다.

데이터 이용과 연구분석 절차는 다음과 같다. 우선, 연구자는 한 국아동패널(PSKC) 홈페이지에서 공공데이터로 활용되고 있는 7차 (2014년), 8차(2015년), 그리고 9차(2016년) 데이터와 조사보고서를 다운받아 내용을 면밀히 살펴보았다. 그리고 연구문제에 따라 KICCE PSKC 데이터를 활용하여 발현 문해능력과 읽기·쓰기 학업능력 과의 관계에 대한상관분석과 의사결정나무모형 분석을 실시하였다.

\section{자료분석}

분석기법

수집된 자료는 IBM SPSS 25.0 프로그램을 사용하여 스피어만 상 관분석(Spearman Correlation)과 데이터 마이닝 기법 중 하나인 의 사결정나무모형 분석(Decision Tree Analysis)을 활용하였다. 의사 결정나무모형 구축을 위한 알고리즘으로는 Chi-squared Automatic Interaction Detector (CHAID; Kass, 1980)를 활용하였다. 의사결정 나무모형 분석은 의사결정 규칙을 나무 구조로 나타내어 전체 자료 를 몇 개의 소집단으로 분류하거나 예측하는 방법이다. 이번 연구는 초등학교 1-2학년 시기에 문해능력을 예측하는 발현 문해능력을 예 측하는 모형을 제시하기 위하여 이러한 분석을 사용하였다.

\section{의사결정나무모형 알고리즘}

의사결정나무모형은 목적변수의 척도와 분리기준으로 사용되 는 알고리즘에 따라 분류할 수 있다. 의사결정나무모형 중 가장 보 
편적으로 사용되는 것은 $\mathrm{CHAID}$ 이다. CHAID는 일반적으로 목 적변수와 질적변수 모두가 질적변수인 경우에 $\chi^{2}$ 검정을 이용하여 분리와 병합을 반복하면서 통계적으로 유의한 차이가 있는 마디를 분류해내는 방법이다.

본 연구에 활용된 CHAID는 기본적으로 다음과 같은 두 가지의 단계를 거쳐서 분리가 일어난다. 첫 번째 단계는 모든 예측변수들 에 대해서 최적분리를 탐색하는 과정으로서, $\chi^{2}$ 통계량 값과 이에 상응하는 $p$ 값을 산출한다. 이 단계에서는 예측변수의 범주 중에 유 의한 차이가 없는 것들을 찾아서 병합도 이루어진다. 두 번째 단계 는 첫 번째 단계에서 계산된 $p$ 값을 비교하여 가장 작은 $p$ 값을 갖는 예측변수를 선택하고 이를 기준으로 자식마디를 형성한다. 이러한 과정을 반복하여 의사결정나무모형이 형성된다(Lee, 2020).

\section{의사결정나무모형 분석}

의사결정나무모형 분석에 있어 국내 초등학교 1,2 학년 아동의 읽기와 쓰기 수행 평가 수준을 목표변수(Target variable)로, 패널 대상자들이 초등학교 입학 전 6세 유치원 시기에 조사한 학업능력 중 14가지 발현 문해능력 변수를 예측변수(predictor variable)로 하여 분석하였다. 그리고 예측변수 분석에 있어 의사결정나무모형 이 데이터에 과적합(overfitting)되는 것을 방지하기 위해 나무의 성장을 멈추는 중지규칙(stopping rule)으로 가지를 이루는 마디의 개수를 의미하는 나무 깊이(depth)를 최대 5 로 제한하였으며, 전체 훈련 데이터에서 비율로써 레코드 수는 부모마디(parent node)의 최소 레코드 수 $2 \%$, 자식마디(child node)의 최소 레코드 수 $1 \%$ 로 설정하였다. 이러한 범위는 목적변수의 설명에 있어 작은 변화를 예측하는 분류변수도 살펴보기 위함이다. 그리고 다양한 범주의 조합을 검증할 때 유의수준은 조정되는 데 유의수준 값을 조정하 기 위해 위양성 오류(false-positive error)의 제어에 효과적인 Bonferroni 방법을 사용하였으며, 분할과 병합을 위한 유의수준은 .05 로 하였다.

\section{연구결과}

\section{빈도분석}

\section{언어 및 발현 문해능력}

'언어 및 발현 문해능력'의 14 문항에 대한 점수화는 '아직 하지 않음(1점), 하기 시작함(2점), 어느 정도 해냄(3점), 잘하는 편임(4점), 능숙함(5점)'과 같은 5점 리커트 척도를 이용하였다. 그리고 패널 대상자의 개인 발달 수준에 따라 본 문항에 적합한 아동이 아닐 경 우는 '해당 없음(0)'에 체크하도록 되어있다. 14 개 모든 문항에 대한
문항별 5 개 척도 포함 대상자 수에 대한 카이제곱 검정 결과는 .001 수준 이하로 유의미하게 차이를 보였다. 그리고 5 개 척도 별 포함 대 상자 수에 대한 유의미한 차이가 가장 높은 문항을 카이제곱 검정 값인 관측값과 기대값 차이 검정결과 순위별로 구분하였을 때는, 문항 10 번('엄마', ‘아빠', '너', '안녕'과 같은 비교적 간단한 단어를 기억해서 쓴다.), 1 번(몇 가지 행동의 연결된 지시를 따를 수 있다.), 8 번(간단한 책을 스스로 읽는다.), 3 번(누군가 읽어준 글이나 이야 기를 이해하고 해석한다.), 2 번(다소 복잡한 문장 구조를 사용한 다.), 5 번(음조가 비슷한 단어[운율 맞추기]를 만들 수 있다.), 11 번 ('대한민국', '좋아한다', '웃는다'와 같은 비교적 복잡한 단어를 기 억해서 쓴다.), 4 번(한글의 모든 자음과 모음을 쉽고 빠르게 말할 수 있다.), 7 번(줄거리의 단서나 그림을 보고 그다음에 어떤 이야기 가 이어질 것인지 예측할 수 있다.), 9번(초기 쓰기 행동을 나타낸 다.), 6 번(읽기 활동을 자주 선택하며 어려워하지 않는다.), 13 번(쓰 기 관련 활동을 자주 선택하며 어려워하지 않는다.), 12 번(쓰기 규 칙을 어느 정도 이해하고 있는 것 같다.), 14 번(컴퓨터를 통해 다양 한 활동을 한다.)의 순으로 차이를 보였다(Table 4).

즉, 초등학교 입학을 앞둔 6 세 학령전 아동의 언어 및 발현 문해 능력 평가 결과, 또래들과 가장 많은 차이를 보이는 문항은 간단한 단어를 쓸 수 있는지와 연결지시에 따라 행동할 수 있는지, 책을 스 스로 읽거나 누군가 읽어준 이야기를 이해하고 해석할 수 있는지와 같은 ‘단어 해독 및 듣기 이해’ 능력이었다. 그리고 ‘이야기 예측과 쓰기, 디지털 문해’에 대한 수준별 또래 집단 구분은 '단어 해독 및 듣기 이해' 영역보다는 집단 차이가 높지 않은 것으로 나타났다.

\section{읽기 \& 쓰기 학업 수행능력}

읽기 및 쓰기 학업 수행능력 평가 점수화는 ‘하위 $20 \%$ 이내(1점), 하위 21-40\% (2점), 중간 50\% 내외(3점), 상위 21-40\% (4점), 상위 $20 \%$ 이내(5점)'와 같은 5점 리커트 척도를 이용하였다. 패널 대상자 들이 초등학교 1학년과 2 학년이 되었을 때, 읽기와 쓰기 수행 능력 수준을 5 개 척도로 구분하여, 카이제곱 검정을 실시한 결과 .001 수준 이하로 모두 유의미하게 차이를 보였다. 학년별(1학년, 2 학년) 수행 수준(읽기, 쓰기)에 대한 5개 척도에서 유의미한 차이가 가장 높은 문항을 카이제곱 검정값인 관측값과 기대값 차이 검정으로 살펴본 결과, 순위별로 구분하였을 때는 1 학년 읽기 $\left(\chi^{2}=916.87\right.$, $\mathrm{df}=4, p=.000), 1$ 학년 쓰기 $\left(\chi^{2}=796.02, \mathrm{df}=4, p=.000\right), 2$ 학년 읽 기 $\left(\chi^{2}=597.38, \mathrm{df}=4, p=.000\right), 2$ 학년 쓰기 $\left(\chi^{2}=498.03, \mathrm{df}=4, p=\right.$ $.000)$ 의 순으로 차이를 보였다(Table 5).

즉, 초등학교 1-2학년 읽기와 쓰기 학업 수행능력의 차이는 초등 학교 1학년 읽기, 쓰기보다는 초등학교 2학년 읽기, 쓰기에서 그 차 


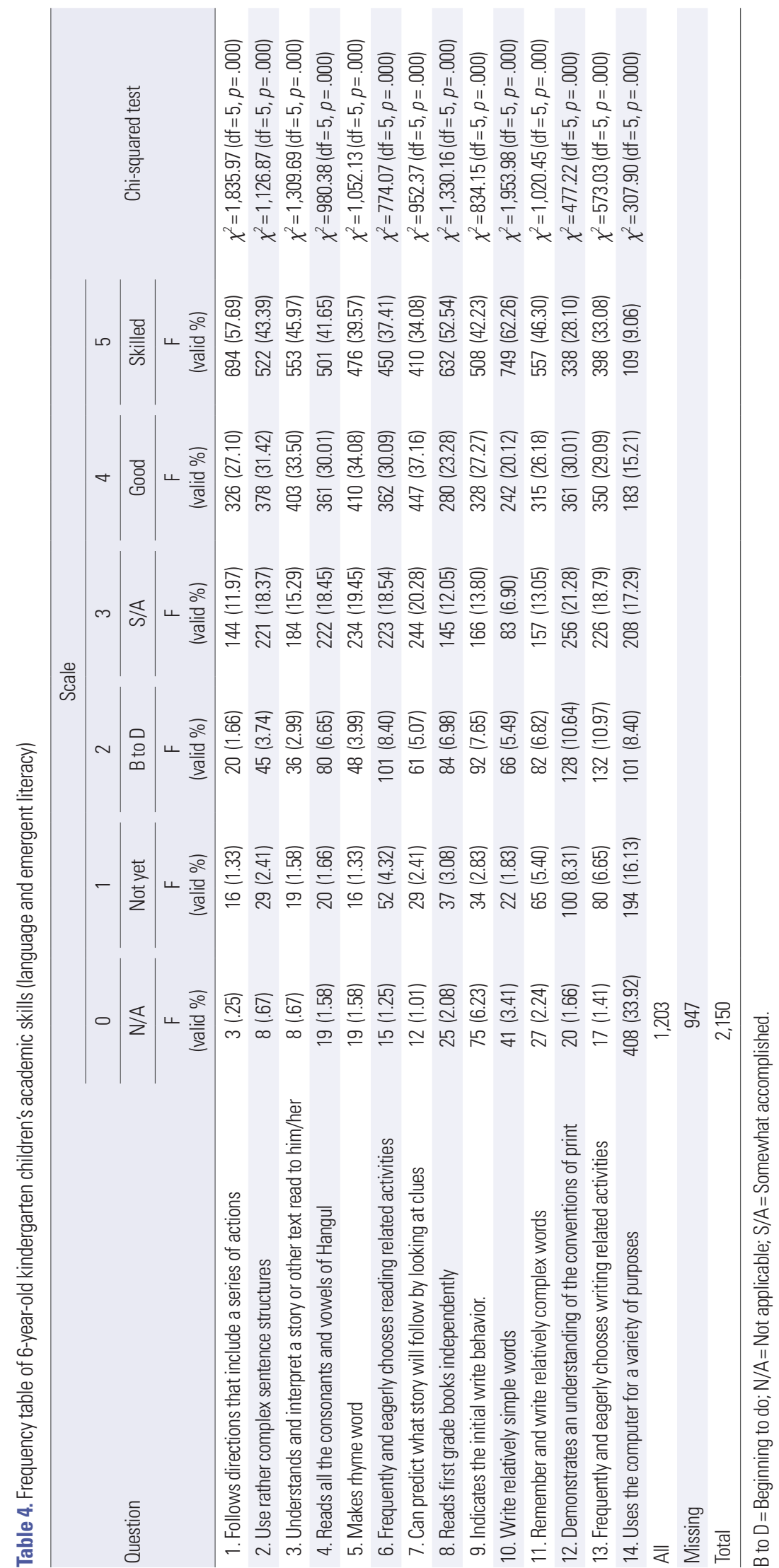

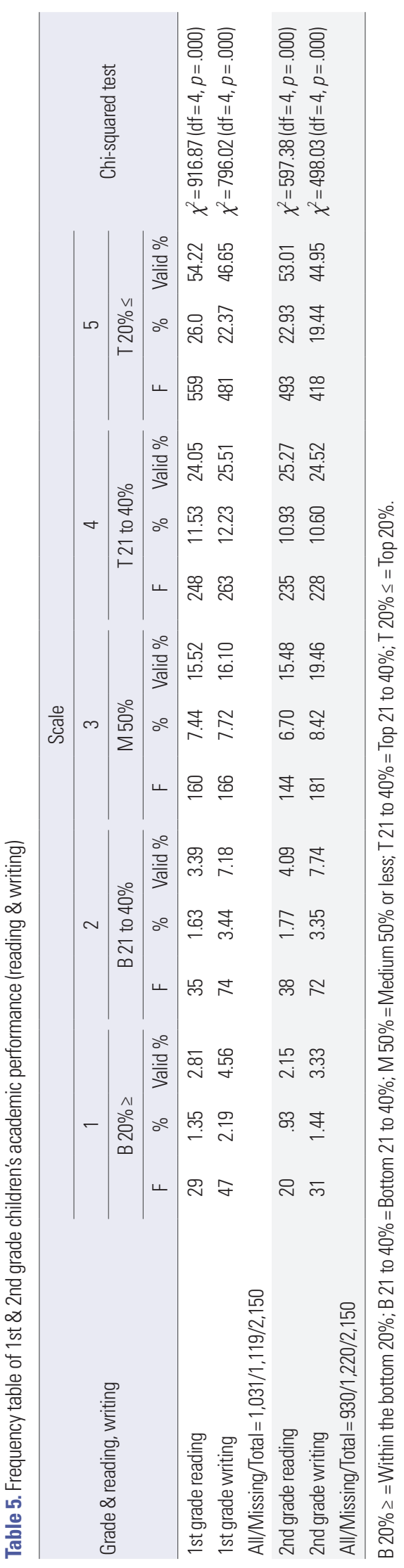


이가 줄어들었지만 여전히 하위 $40 \%$ 이하의 수준 아동은 연령 증 가와상관없이 계속적으로 지속되는 것을 알 수 있었다.

\section{연구결과 1. 학령전 언어 및 발현 문해능력과 초등학교 1-2학년 읽기 \& 쓰기 수행과의 상관관계}

6 세 때의 '언어 및 발현 문해능력' 14 문항과 초등학교 1,2학년 때 의 ‘읽기 및 쓰기 학업 수행능력' 평가 결과 간의 상관분석 결과는 Table 6에 제시하였다.

상관분석 결과 언어 및 발현 문해능력 14 번(컴퓨터를 통해 다양 한 활동을 한다.)을 제외한 모든 문항들은 유의수준 .001에서 유의 한 상관을 보였다. 그리고 읽기 및 쓰기 학업 수행능력은 1학년 읽 기와 쓰기 간에 그리고 2학년 읽기와 쓰기 간의 상관계수는 .80 이 상으로 매우 높은 것으로 나타났다.

언어 및 발현 문해능력 14 번 문항(컴퓨터를 통해 다양한 활동을 한다.)은 읽기와 쓰기 수행능력 정도와 유의미한 상관관계가 없었 다. 하지만 발현 문해능력 개별 문항 14 가지 중 컴퓨터를 통해 다양 한 활동을 하는 것과 관련 있는 발현 문해능력은 다음과 같은 것들 이었다. 발현 문해능력 문항 2 번(다소 복잡한 문장 구조를 사용한 다; rho=.07, $p<.05$ ), 6 번(읽기 활동을 자주 선택하며 어려워하지
않는다; $\mathrm{rho}=.08, p<.001$ ), 7 번(줄거리의 단서나 그림을 보고 그다 음에 어떤 이야기가 이어질 것인지 예측할수 있다; rho=.09, $p<.001$ ), 9번(초기 쓰기 행동을 나타낸다; rho=.09, $p<.001$ ), 11번('대한민 국', '좋아한다', '웃는다'와 같은 비교적 복잡한 단어를 기억해서 쓴 다; rho=.07, $p<.05$ ), 12 번(쓰기 규칙을 어느 정도 이해하고 있는 것 같다; $\mathrm{rho}=.20, p<.001$ ), 13 번(쓰기 관련 활동을 자주 선택하며 어려워하지 않는다; rho=.16, $p<.001) 7$ 개 문항이었다. 즉, 학령전 에 컴퓨터를 통해 다양한 활동을 한다는 것은 읽기와 쓰기를 자주 선택하며 어려워하지 않는다는 것과 관련은 있지만 이후 학령기 초 기의 문해력에 영향을 미치는 것은 아닌 것으로 나타났다.

\section{연구결과 2. 초등학교 1학년 읽기 수준을 예측하는 학령전 발현 문해능력} 의사결정나무모형 분석

평균 만 7세(초등학교 1학년) 국내 일반 아동들의 읽기 수준(Target variable)을 예측하는 6세 학령전 아동의 언어 및 발현 문해능력 에는 14 가지가 예측변수(Predictor variable)가 포함되었다.

목표변수인 읽기 수준 변수는 '하위 20\% 이내(1점), 하위 $21-40 \%$ (2점), 중간 $50 \%$ 내외(3점), 상위 $21-40 \%$ (4점), 상위 $20 \%$ 이내(5점)'

Table 6. Spearman correlation between academic skills (language and emergent literacy) and academic performance (reading \& writing)

\begin{tabular}{|c|c|c|c|c|c|c|c|c|c|c|c|c|c|c|c|c|c|c|c|}
\hline & & \multicolumn{18}{|c|}{ Scores } \\
\hline & & R1 & W1 & R2 & W2 & 1 & 2 & 3 & 4 & 5 & 6 & 7 & 8 & 9 & 10 & 11 & 12 & 13 & 14 \\
\hline \multicolumn{20}{|l|}{ AP } \\
\hline Reading Performance of 1 st grade & $\mathrm{R} 1$ & - & & & & & & & & & & & & & & & & & \\
\hline Writing Performance of 1 st grade & W1 & $.84^{* *}$ & - & & & & & & & & & & & & & & & & \\
\hline Reading Performance of 2 nd grade & $\mathrm{R} 2$ & $.47^{* *}$ & $.47^{* *}$ & - & & & & & & & & & & & & & & & \\
\hline Writing Performance of $2 n d$ grade & W2 & $.47^{* *}$ & $.49^{* *}$ & $.82^{* *}$ & - & & & & & & & & & & & & & & \\
\hline \multicolumn{20}{|l|}{$A C$} \\
\hline Follows directions & 1 & $.28^{* *}$ & $.26^{* *}$ & $.22^{* *}$ & $.22^{* *}$ & - & & & & & & & & & & & & & \\
\hline Use complex sentence structures & 2 & $.27^{* *}$ & $.25^{* *}$ & $.21^{* *}$ & $.21^{* *}$ & $.53^{* *}$ & - & & & & & & & & & & & & \\
\hline Understands and interpret a story & 3 & $.29^{* *}$ & $.28^{* *}$ & $.26^{* *}$ & $.25^{* *}$ & $.50^{* *}$ & $.68^{* *}$ & - & & & & & & & & & & & \\
\hline Can say all the consonants and vowels & 4 & $.35^{* *}$ & $.34^{* *}$ & $.32^{* *}$ & $.31^{* *}$ & $.44^{* *}$ & $.55^{* *}$ & $.61^{* *}$ & - & & & & & & & & & & \\
\hline Makes rhyme word & 5 & $.35^{* *}$ & $.33^{* *}$ & $.31^{* *}$ & $.30^{* *}$ & $.40^{* *}$ & $.51^{* *}$ & $.58^{* *}$ & $.71^{* *}$ & - & & & & & & & & & \\
\hline Frequently and eagerly chooses reading & 6 & $.40^{* *}$ & $.38^{* *}$ & $.34^{* *}$ & $.34^{* *}$ & $.41^{* *}$ & $.48^{* *}$ & $.54^{* *}$ & $.67^{* *}$ & $.62^{* *}$ & - & & & & & & & & \\
\hline Can predict what story will follow & 7 & $.34^{* *}$ & $.32^{* *}$ & $.28^{* *}$ & $.27^{* *}$ & $.41^{* *}$ & $.54^{* *}$ & $.63^{* *}$ & $.59^{* *}$ & $.63^{* *}$ & $.66^{* *}$ & - & & & & & & & \\
\hline Reads first grade books independently & 8 & $.37^{* *}$ & $.32^{* *}$ & $.37^{* *}$ & $.36^{* *}$ & $.41^{* *}$ & $.45^{* *}$ & $.51^{* *}$ & $.61^{* *}$ & $.56^{* *}$ & $.71^{* *}$ & $.59 * *$ & - & & & & & & \\
\hline Indicates the initial write behavior. & 9 & $.26^{* *}$ & $.37^{* *}$ & $.26^{* *}$ & $.27^{* *}$ & $.30^{* *}$ & $.35^{* *}$ & $.37^{* *}$ & $.47^{* *}$ & $.44^{* *}$ & $.48^{* *}$ & $.45^{* *}$ & $.55^{* *}$ & - & & & & & \\
\hline Write relatively simple words & 10 & $.35^{* *}$ & $.28^{* *}$ & $.32^{* *}$ & $.32^{* *}$ & $.39 * *$ & $.38^{* *}$ & $.44^{* *}$ & $.54^{* *}$ & $.48^{* *}$ & $.54^{* *}$ & $.46^{* *}$ & $.66^{* *}$ & $.56^{* *}$ & - & & & & \\
\hline Remember and write complex words & 11 & $.34^{* *}$ & $.36^{* *}$ & $.31^{* *}$ & $.32^{* *}$ & $.37^{* *}$ & $.42^{* *}$ & $.46^{* *}$ & $.57^{* *}$ & $.53^{* *}$ & $.59 * *$ & $.52^{* *}$ & $.65^{* *}$ & $.54^{* *}$ & $.70^{* *}$ & - & & & \\
\hline Demonstrates an understanding of & 12 & $.32^{* *}$ & $.33^{* *}$ & $.29^{* *}$ & $.31^{* *}$ & $.32^{* *}$ & $.35^{* *}$ & $.41^{* *}$ & $.53^{* *}$ & $.51^{* *}$ & $.57^{* *}$ & $.52^{* *}$ & $.55^{* *}$ & $.48^{* *}$ & $.53^{* *}$ & $.67^{* *}$ & - & & \\
\hline Frequently and eagerly chooses writing & 13 & $.35^{* *}$ & $.37^{* *}$ & $.33^{* *}$ & $.35^{* *}$ & $.38^{* *}$ & $.41^{* *}$ & .49 & $.59^{* *}$ & $.55^{* *}$ & $.65^{* *}$ & $.56^{* *}$ & $.61^{* *}$ & $.48^{* *}$ & $.56^{* *}$ & $.67^{* *}$ & $.73^{* *}$ & - & \\
\hline Uses the computer for a variety of purposes & 14 & - & - & - & - & - & $.07^{*}$ & - & - & - & $.08^{* *}$ & $.09 * *$ & -.011 & $.09 * *$ & -.027 & $.07^{*}$ & $.20^{* *}$ & $.16^{* *}$ & - \\
\hline
\end{tabular}

${ }^{*} p<.05,{ }^{* *} p<.001$.

$\mathrm{AP}=$ academic performance; $\mathrm{AC}=$ academic skills. 
의 5 점 리커트 척도(Likert scale)를 이용하였다. 또한 14 개 예측변 수도 '아직 하지 않음(1점), 하기 시작함(2점), 어느 정도 해냄(3점), 잘하는 편임(4점), 능숙함(5점)'과 같은 5점 리커트 척도를 이용하 였다. 그리고 중지규칙(stopping rule)으로 가지를 이루는 마디의 개수를 의미하는 나무 깊이(depth)를 최대 5 로 제한한 결과, 4 마디 깊이 4 에서 정지하였다.

분석결과 Figure 1에서 알 수 있듯이, 1학년 아동의 읽기 수준에 대한 첫 번째 분리는 언어 및 발현 문해능력 문항 8 (간단한 책을 스 스로 읽는다.) 수준에 의하여 이루어졌다. 첫 번째 분리는 초등학교 1 학년 아동이 간단한 책을 스스로 읽는 수준이 '상위 $20 \%$ '에 속하 는 집단(454명, 52.4\%)과 ‘중간 50\%-상위 40\%' 집단(202명, 23.3\%), '하위 21-중간 $50 \%$ 내외' 집단(105명, $12.1 \%$ ), '하위 $40 \%$ 이하' 집단 (106명, 12.2\%)으로 구분하여 이루어졌다 $\left(\chi^{2}=191.61, \mathrm{df}=12, p=.00\right)$. 그리고 4번 마디(Node 4)를 자세히 살펴보면 간단한 책을 스스로 읽는 수준이 상위 $20 \%$ 이내로 평가된 집단 내에는 전체 언어 및 발 현 문해능력 수준이 '상위 $20 \%$ 이내' 수준으로 평가된 아동이 308 명(67.8\%)으로 가장 많이 포함되어 있지만, 이외의 집단도 146 명 (32.2\%)이 포함되어 있다.
Figure 1에서 간단한 책을 스스로 읽는 수준이 '상위 $20 \%$ 이내'로 평가된 집단은 4번(Node 4)과 7번(Node 7), 8 번(Node 8), 9 번(Node 9), 10번(Node 10) 마디를 하나의 가지(branch)로 이루고 있으며, 그 가지의 깊이는 3이었다. 그리고 간단한 책을 스스로 읽는 수준이 '상위 $20 \%$ 이내'로 평가된 아동은 언어 및 발현 문해능력 문항 12 (쓰기 규칙을 어느 정도 이해하고 있는 것 같다.) 수준에서 '상위 $40 \%$ 이내(383명, $44.2 \%)$ '와 '중간 $50 \%$ 이하-(71명, $8.2 \%)$ ' 집단으로 구분할 수 있었다 $\left(\chi^{2}=15.74, \mathrm{df}=4, p=.01\right)$. 그리고 마지막 깊이 3 에 서는 언어 및 발현 문해능력 문항 1 (몇 가지 행동의 연결된 지시를 따를 수 있다.) 수준 '상위 $20 \%$ 이내(290명, 33.4\%)'와 '상위 $21 \%$ 이하 (93명, 10.7\%)' 집단으로 구분되었다 $\left(\chi^{2}=17.46, \mathrm{df}=3, p=.001\right)$. 즉, 1 학년 아동의 읽기 수준은 유치원 시기에 '간단한 책을 스스로 읽 을 수 있으며, 쓰기 규칙을 어느 정도 이해하고, 몇 가지 행동의 연 결된 지시를 따를 수 있다.와 같은 언어 및 발현 문해능력에 의해 상위 $20 \%$ 를 예측할 수 있는 것으로 나타났다.

이외 간단한 책을 스스로 읽는 수준이 중간(중간 50\%-상위 21\%) 정도인 1 학년 집단은 3 번, 5 번, 6 번 마디를 하나의 가지로 이루고 있 었다. 그리고 가지의 마지막 깊이 2 에서 언어 및 발현 문해능력 문항

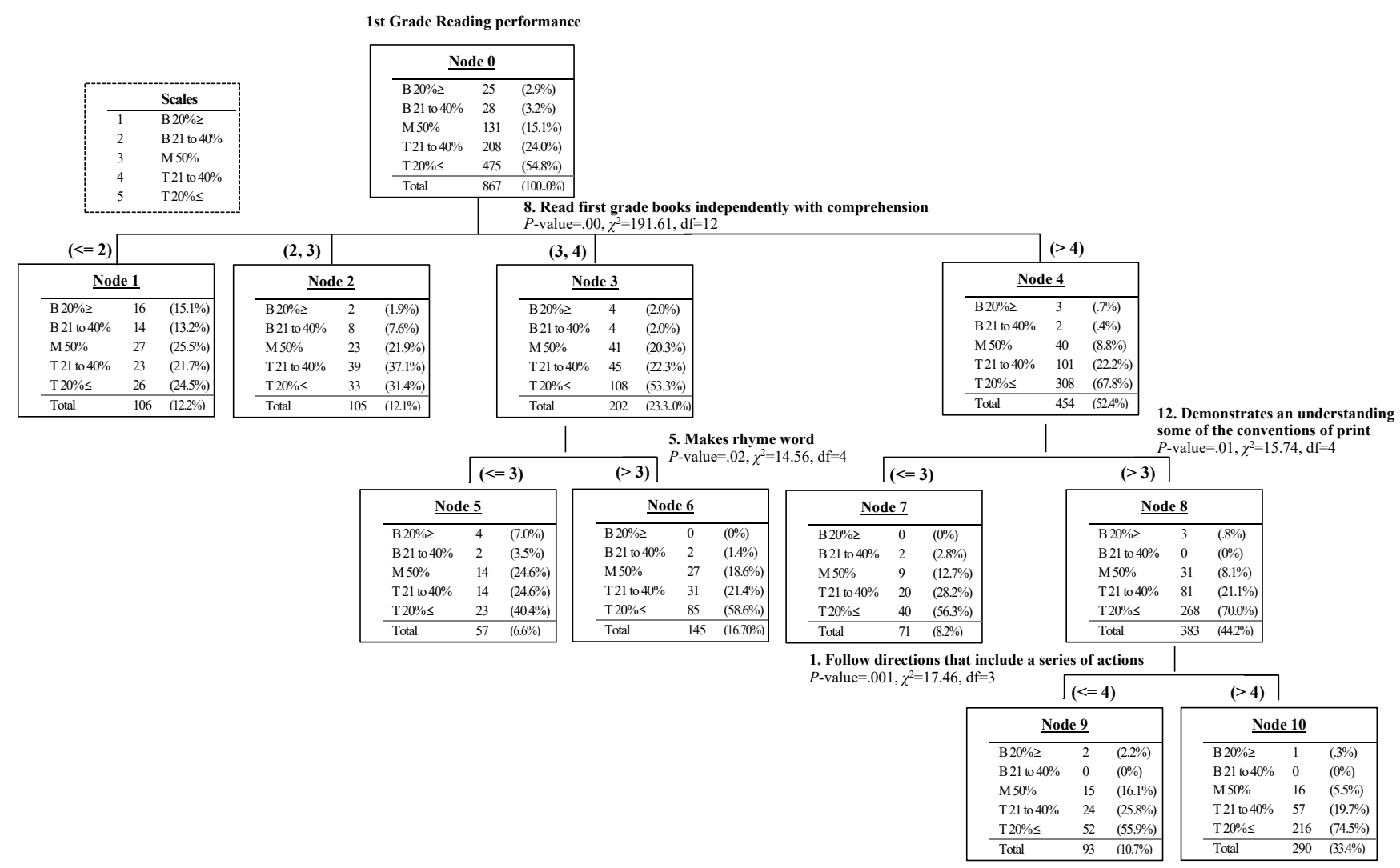

Figure 1. Decision tree model of language \& emergent literacy to predict reading performance in first-year elementary school students. 
5 (음조가 비슷한 단어[운율 맞추기]를 만들 수 있다.) 수준이 '상위 $40 \%$ 이내'와 '상위 $40 \%$ 이하' 집단으로 구분되었다 $\left(\chi^{2}=14.56, \mathrm{df}=4\right.$, $p=.02)$. 즉, 1 학년 아동의 읽기 수준은 유치원 시기에 '간단한 책을 스스로 읽을 수 있는 수준이 '중간 50\%-상위 21\%'에 포함되는 아 동이었다면, 음조가 비슷한 단어(운율 맞추기)를 만들 수 있는 정

Table 7. Prediction rate (accuracy) \& risk of model

\begin{tabular}{lcccccc}
\hline \multirow{2}{*}{ Data } & \multicolumn{7}{c}{ Prediction } \\
\cline { 2 - 7 } & 1 & 2 & 3 & 4 & 5 & Accuracy (\%) \\
\hline 1 B 20\% $\geq$ & 0 & 0 & 16 & 2 & 7 & 0 \\
2 B 21 to 40\% & 0 & 0 & 14 & 8 & 6 & 0 \\
3 M 50\% & 0 & 0 & 27 & 23 & 81 & 20.61 \\
4 T 21 to 40\% & 0 & 0 & 23 & 39 & 146 & 18.58 \\
5 T 20\% $\leq$ & 0 & 0 & 26 & 33 & 416 & 87.57 \\
A Total (\%) & .0 & .0 & 12.23 & 12.11 & 75.66 & 55.59 \\
\hline & \multicolumn{7}{c}{ Risk of model } \\
\hline Risk estimate & \multicolumn{7}{c}{.463} \\
SE of risk estimate & \multicolumn{7}{c}{017} \\
\hline
\end{tabular}

Target variable: Reading performance, Growth method: CHAID.
도가 '상위 $40 \%$ 이상'일 때 초등학교 1학년 읽기 수준에 차이를 보 이는 집단으로 구분될 수 있었다(Figure 1).

\section{모형 평가}

1 학년 읽기 수준에 대한 학령 전 언어 및 발현 문해능력 예측변 수 의사결정나무에 대한 평가는 정확성과 위험도표를 통해 진행하 였다. 전체 예측 정확성은 55.59\%였으며, 읽기 수준 상위 $20 \%$ 이내 집단에 대한 언어 및 발현 문해능력의 예측 정확성은 $87.57 \%$ 로 높 았으나 이외 수준의 예측 정확성은 $20 \%$ 이하로 높지 않았다. 그리 고 예측위험(risk estimate)은 $.463(46.3 \%)$ 이었다(Table 7).

\section{연구결과 3. 초등학교 1학년 쓰기 수준을 예측하는 학령전 발현 문해능력}

\section{의사결정나무모형 분석}

평균 만 7세(초등학교 1학년) 국내 일반 아동들의 쓰기 수준(Target variable)을 예측하는 6세 학령전 아동의 언어 및 발현 문해능력 에는 14 가지가 예측변수(Predictor variable)가 포함되었다.

1st Grade Writing performance

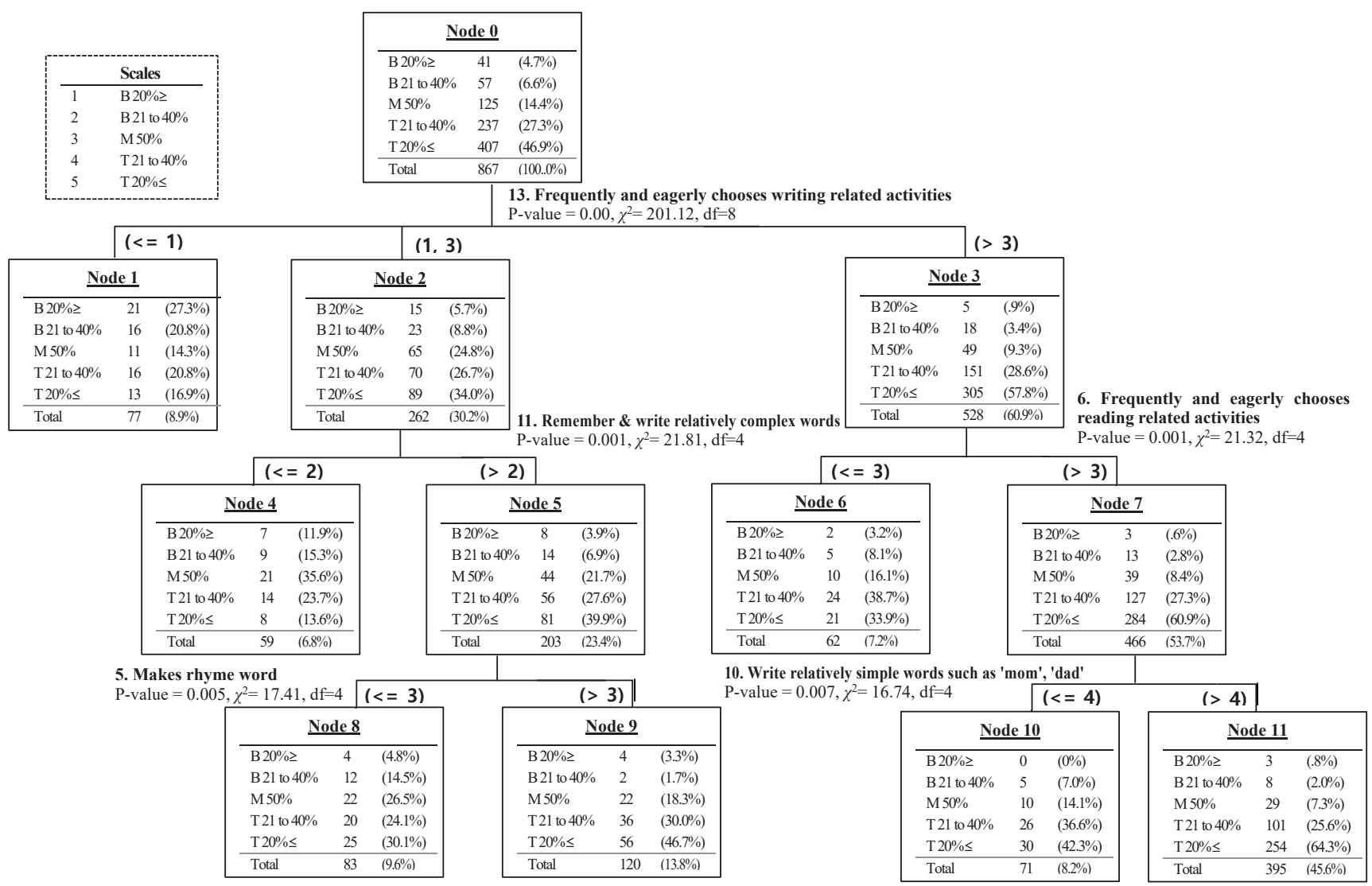

Figure 2. Decision tree model of language \& emergent literacy to predict writing performance in first-year elementary school students. 
목표변수인 쓰기 수준 변수는 ‘하위 20\% 이내(1점), 하위 21-40\% (2점), 중간 50\% 내외(3점), 상위 21-40\% (4점), 상위 20\% 이내(5점) 의 5 점 리커트 척도를 이용하였다. 또한 14 개 예측변수도 '아직 하지 않음(1점), 하기 시작함(2점), 어느정도 해냄(3점), 잘하는 편임(4점), 능숙함(5점)'과 같은 5점 리커트 척도를 이용하였다. 그리고 중지규 칙(stopping rule)으로 가지를 이루는 마디의 개수를 의미하는 나무 깊이(depth)를 최대 5 로 제한한 결과, 4 마디 깊이 4 에서 정지하였다.

분석 결과 Figure 2에서 알 수 있듯이, 1학년 아동의 쓰기 수준에 대한 첫 번째 분리는 언어 및 발현 문해능력 문항 13 (쓰기 관련 활 동을 자주 선택하며 어려워하지 않는다.) 수준에 의하여 이루어졌 다. 첫 번째 분리는 초등학교 1 학년 아동이 쓰기 관련 활동을 자주 선택하며 어려워하지 않는 수준이 '상위 $40 \%$ 이내'에 속하는 집단 (528명, 60.9\%)과 '중간 $50 \%$ 이하' 집단(262명, $30.2 \%$ ), ‘하위 $20 \%$ 이 내' 집단(77명, 8.9\%)으로 구분하여 이루어졌다 $\left(\chi^{2}=201.12, \mathrm{df}=8\right.$, $p=.00$ ). 그리고 3 번 마디(Node 3)를 자세히 살펴보면 쓰기 관련 활 동을 자주 선택하며 어려워하지 않는 수준이 상위 $40 \%$ 이내로 평 가된 집단 내에는 전체 언어 및 발현 문해능력 수준이 '상위 $20 \%$ 이 내' 수준으로 평가된 아동이 305명(57.8\%) 그리고 '상위 21-40\%' 수 준으로 평가된 아동이 151 명(28.6\%)으로 가장 많이 포함되어 있지 만, 이외의 집단도 72 명(13.6\%)이 포함되어 있다.

Figure 2에서 쓰기 관련 활동을 자주 선택하며 어려워하지 않는 다는 수준이 상위 $40 \%$ 이내'로 평가된 집단은 3번(Node 3)과 6번 (Node 6), 7번(Node 7), 10번(Node 10), 11번(Node 11) 마디를 하나 의 가지(branch)로 이루고 있으며, 그 가지의 깊이는 3이었다. 쓰기 관련 활동을 자주 선택하며 어려워하지 않는다는 수준이 '상위 $40 \%$ 이내'로 평가된 아동은 언어 및 발현 문해능력 문항 6 (읽기 활동을 자주 선택하며 어려워하지 않는다.) 수준에서 '상위 $40 \%$ 이내(466 명, 53.7\%)'와 '중간 50\% 이하(62명, 7.2\%)' 집단으로 구분할 수 있었 다 $\left(\chi^{2}=21.32, \mathrm{df}=4, p=.001\right)$. 그리고 마지막 깊이 3 에서는 언어 및 발현 문해능력 문항 10 ('엄마', '아빠', '너', '안녕'과 같은 비교적 간 단한 단어를 기억해서 쓴다.) 수준 '상위 $20 \%$ 이내(395명, $45.6 \%$ '와 '상위 $21 \%$ 이하 $(71$ 명, $8.2 \%)$ ' 집단으로 구분되었다 $\left(\chi^{2}=16.74, \mathrm{df}=4\right.$, $p=.007)$. 즉, 1 학년 아동의 쓰기 수준은 유치원 시기에 '쓰기 관련 활동을 자주 선택하며 어려워하지 않으며, 읽기 활동을 자주 선택 하며 어려워하지 않고, ‘엄마', ‘아빠', ‘너', ‘안녕'과 같은 비교적 간단 한 단어를 기억해서 쓴다.와같은 언어 및 발현 문해능력에 의해 상 위 $20 \%$ 를 예측할 수 있는 것으로 나타났다.

이외 간단한 쓰기 관련 활동을 자주 선택하며 어려워하지 않는 수준이 중간 이하(하위 $20 \%$-중간 $50 \%$ ) 정도인 1학년 집단은 2번, 4 번, 5 번, 8 번, 9 번 마디를 하나의 가지로 이루고 있었다. 가지의 깊이
2에서 언어 및 발현 문해능력 문항 11 ('대한민국', '좋아한다', '웃는 다'와 같은 비교적 복잡한 단어를 기억해서 쓴다.) 수준이 '상위 $20 \%$ 이내'와 '상위 $20 \%$ 이하' 집단으로 구분되었다 $\left(\chi^{2}=21.81, \mathrm{df}=4\right.$, $p=.001)$. 그리고 가지의 깊이 3 에서 언어 및 발현 문해능력 문항 5(음조가 비슷한 단어[운율 맞추기]를 만들 수 있다.) 수준이 '상위 $40 \%$ 이내'와 '상위 $40 \%$ 이하' 집단으로 구분되었다 $\left(\chi^{2}=17.41, \mathrm{df}=4\right.$, $p=.005)$. 즉, 1 학년 아동의 쓰기 수준은 유치원 시기에 쓰기 관련 활 동을 자주 선택하며 어려워하지 않는 수준이 ‘하위 20\%-중간 50\%' 포함되는 아동이었다면, '대한민국', ‘좋아한다', ‘웃는다'와 같은 비 교적 복잡한 단어를 기억해서 쓰고, 음조가 비슷한 단어(운율 맞추 기)를 만들 수 있는 정도가 '상위 $40 \%$ 이상'일 때 초등학교 1학년 쓰 기수준에 차이를 보이는 집단으로 구분될 수 있었다(Figure 2).

\section{모형 평가}

1 학년 쓰기 수준에 대한 학령전 언어 및 발현 문해능력 예측변수 의사결정나무에 대한 평가는 정확성과 위험도표를 통해 진행하였 다. 전체 예측 정확성은 $49.71 \%$ 였으며, 읽기 수준 상위 $20 \%$ 이내 집 단에 대한 언어 및 발현 문해능력의 예측 정확성은 $89.68 \%$ 로 높았 으나 이외 수준의 예측 정확성은 $17 \%$ 미만으로 높지 않았다. 그리 고 예측위험(risk estimate)은 .503 (50.3\%)이었다(Table 8).

\section{연구결과 4. 초등학교 2학년 읽기 수준을 예측하는 학령전 발현 문해능력}

\section{의사결정나무모형 분석}

평균 만 8세(초등학교 2학년) 국내 일반 아동들의 읽기 수준(Target variable)을 예측하는 6세 학령전 아동의 언어 및 발현 문해능력 에는 14 가지가 예측변수(Predictor variable)가 포함되었다.

목표변수인 읽기 수준 변수는 '하위 $20 \%$ 이내(1점), 하위 $21-40 \%$

Table 8. Prediction rate (accuracy) \& risk of model

\begin{tabular}{lrrrrrc}
\hline \multirow{2}{*}{ Data } & \multicolumn{7}{c}{ Prediction } \\
\cline { 2 - 7 } & 1 & 2 & 3 & 4 & 5 & Accuracy (\%) \\
\hline 1 B 20\% $\geq$ & 21 & 0 & 7 & 2 & 11 & 51.22 \\
2 B 21 to 40\% & 16 & 0 & 9 & 5 & 27 & 0 \\
3 M 50\% & 11 & 0 & 21 & 10 & 83 & 16.80 \\
4 T 21 to 40\% & 16 & 0 & 14 & 24 & 183 & 10.13 \\
5 T 20\% & 13 & 0 & 8 & 21 & 365 & 89.68 \\
A Total (\%) & 8.88 & 0 & 6.81 & 7.15 & 77.16 & 49.71 \\
\hline & \multicolumn{7}{c}{ Risk of model } \\
\hline Risk estimate & \multicolumn{7}{c}{.503} \\
SE of risk estimate & \multicolumn{7}{c}{017} \\
\hline
\end{tabular}

Target variable: Reading performance, Growth method: CHAID. 
(2점), 중간 50\% 내외(3점), 상위 21-40\% (4점), 상위 $20 \%$ 이내(5점)' 의 5점 리커트 척도를 이용하였다. 또한 14 개 예측변수도 '아직 하 지 않음(1점), 하기 시작함(2점), 어느 정도 해냄(3점), 잘하는 편임(4 점), 능숙함(5점)'과 같은 5점 리커트 척도를 이용하였다. 그리고 중 지규칙(stopping rule)으로 가지를 이루는 마디의 개수를 의미하는 나무 깊이(depth)를 최대 5로 제한한 결과, 5 마디 깊이 3 에서 정지 하였다.

분석 결과 Figure 3 에서 알 수 있듯이, 2 학년 아동의 읽기 수준에 대한 첫 번째 분리는 언어 및 발현 문해능력 문항 8 (간단한 책을 스 스로 읽는다.) 수준에 의하여 이루어졌다. 첫 번째 분리는 초등학교 1 학년 아동이 간단한 책을 스스로 읽는 수준이 '상위 $20 \%$ '에 속하 는 집단(414명, 52.7\%)과 ‘중간 50\%-상위 40\%' 집단(184명, 23.4\%), '하위 21-중간 $50 \%$ 내외' 집단(94명, $12.0 \%$ ), '하위 $40 \%$ 이하' 집단 (93명, $11.8 \%)$ 으로 구분하여 이루어졌다 $\left(\chi^{2}=167.08, \mathrm{df}=12, p=.00\right)$. 그리고 4 번 마디(Node 4)를 자세히 살펴보면 간단한 책을 스스로 읽는 수준이 상위 $20 \%$ 이내로 평가된 집단 내에는 전체 언어 및 발 현 문해능력 수준이 '상위 $20 \%$ 이내' 수준으로 평가된 아동이 279 명(67.4\%)으로 가장 많이 포함되어 있지만, 이외의 집단도 135 명 (32.6\%)이 포함되어 있다.
Figure 3에서 간단한 책을 스스로 읽는 수준이 '상위 $20 \%$ 이내' 로 평가된 집단은 4 번(Node 4)과 5번(Node 5), 6 번(Node 6) 마디를 하나의 가지(branch)로 이루고 있으며, 그 가지의 깊이는 2이었다. 그리고 간단한 책을 스스로 읽는 수준이 '상위 $20 \%$ 이내'로 평가된 아동은 언어 및 발현 문해능력 문항 1 (몇 가지 행동의 연결된 지시 를 따를 수 있다.) 수준에서 '상위 20\% 이내(307명, 39.1\%)'와 '상위 $20 \%$ 이하(107명, $13.6 \%)^{\prime}$ 집단으로 구분할 수 있었다 $\left(\chi^{2}=11.16\right.$, $\mathrm{df}=4, p=.05)$. 즉, 2 학년 아동의 읽기 수준은 유치원 시기에 '간단 한 책을 스스로 읽을 수 있으며, 몇 가지 행동의 연결된 지시를 따 를 수 있다'와 같은 언어 및 발현 문해능력에 의해 상위 $20 \%$ 를 예측 할 수 있는 것으로 나타났다(Figure 3).

\section{모형 평가}

2학년 읽기 수준에 대한 학령전 언어 및 발현 문해능력 예측변수 의사결정나무에 대한 평가는 정확성과 위험도표를 통해 진행하였 다. 전체 예측 정확성은 $53.76 \%$ 였으며, 읽기 수준 상위 $20 \%$ 이내 집 단에 대한 언어 및 발현 문해능력의 예측 정확성은 $93.11 \%$ 로 높았 으나 이외 수준의 예측 정확성은 $25 \%$ 미만으로 높지 않았다. 그리 고 예측위험(risk estimate)은 .462(46.2\%)이었다(Table 9).

2nd Grade Reading performance

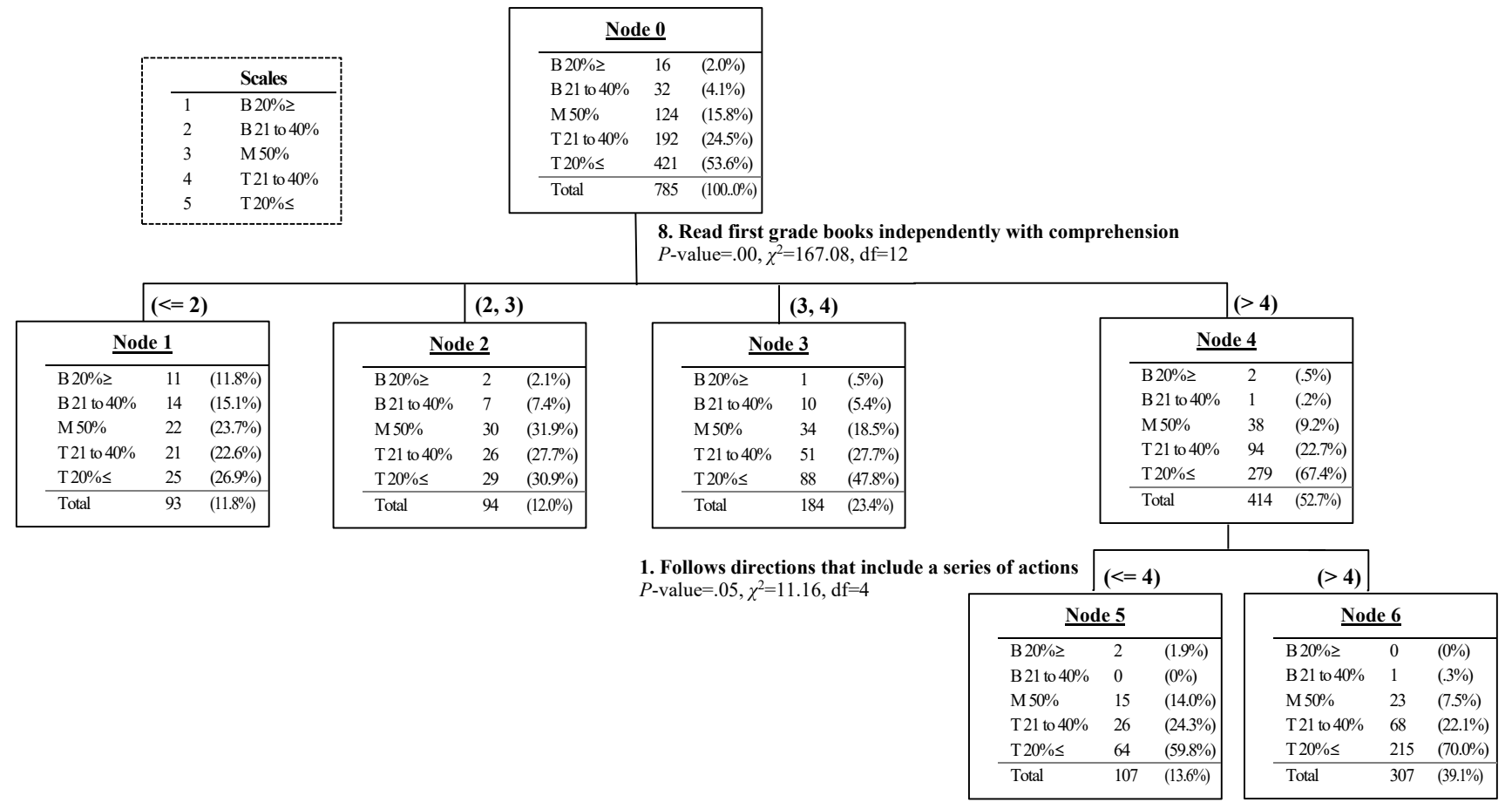

Figure 3. Decision tree model of language \& emergent literacy to predict reading performance in second-year elementary school students. 


\section{연구결과 5. 초등학교 2학년 쓰기 수준을 예측하는 학령전 발현 문해능력}

\section{의사결정나무모형 분석}

평균 만 8세(초등학교 2학년) 국내 일반 아동들의 쓰기 수준(Target variable)을 예측하는 6세 학령전 아동의 언어 및 발현 문해능력 에는 14 가지가 예측변수(Predictor variable)가 포함되었다.

목표변수인 쓰기 수준 변수는 '하위 $20 \%$ 이내(1점), 하위 21-40\% (2점), 중간 50\% 내외(3점), 상위 21-40\%(4점), 상위 $20 \%$ 이내(5점)' 의 5점 리커트 척도를 이용하였다. 또한 14 개 예측변수도 '아직 하 지 않음(1점), 하기 시작함(2점), 어느 정도 해냄(3점), 잘하는 편임(4

Table 9. Prediction rate (accuracy) \& risk of model

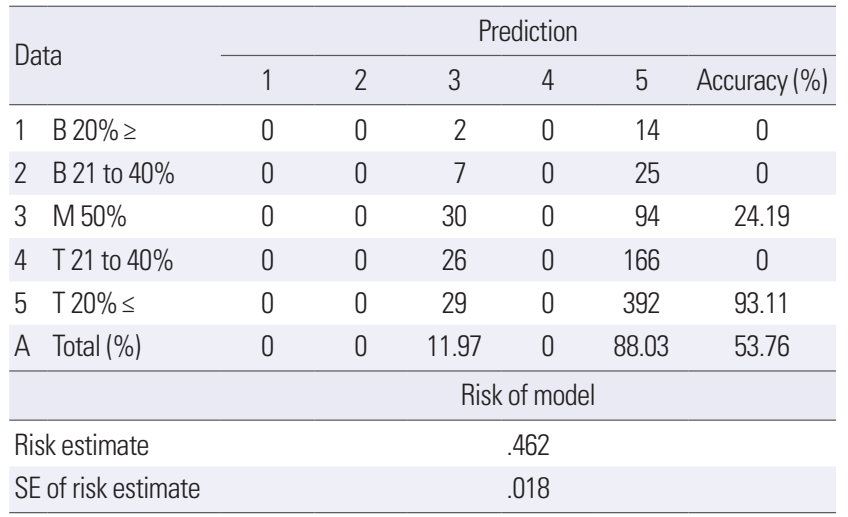

Target variable: Reading performance, Growth method: CHAID.
점), 능숙함(5점)'과 같은 5점 리커트 척도를 이용하였다. 그리고 중 지규칙(stopping rule)으로 가지를 이루는 마디의 개수를 의미하는 나무 깊이(depth)를 최대 5로 제한한 결과, 8 마디 깊이 3 에서 정지 하였다.

분석 결과 Figure 4 에서 알 수 있듯이, 2학년 아동의 쓰기 수준에 대한 첫 번째 분리는 언어 및 발현 문해능력 문항 13 (쓰기 관련 활 동을 자주 선택하며 어려워하지 않는다.) 수준에 의하여 이루어졌 다. 첫 번째 분리는 초등학교 1 학년 아동이 쓰기 관련 활동을 자주 선택하며 어려워하지 않는 수준이 '상위 $20 \%$ 이내'에 속하는 집단 (263명, 33.5\%)과 ‘중간 50\%-상위 20\% 이하' 집단(223명, 28.4\%), '하위 $20 \%$-중간 $50 \%$ 이하' 집단(232명, $29.6 \%$ ), ‘하위 20 이하' 집단 (67명, 8.5\%)으로 구분하여 이루어졌다 $\left(\chi^{2}=171.03, \mathrm{df}=12, p=.00\right)$. 그리고 4 번 마디(Node 4)를 자세히 살펴보면 쓰기 관련 활동을 자 주 선택하며 어려워하지 않는 수준이 상위 $20 \%$ 이내로 평가된 집 단 내에는 전체 언어 및 발현 문해능력 수준이 '상위 $20 \%$ 이내' 수 준으로 평가된 아동이 159명(60.5\%) 그리고 '상위 21-40\%' 수준으 로 평가된 아동이 67명(25.5\%)으로 가장 많이 포함되어 있지만, 이 외의 집단도 37 명(14.0\%)이 포함되어 있다.

Figure 4에서 쓰기 관련 활동을 자주 선택하며 어려워하지 않는 다는 수준이 '상위 $20 \%$ 이내'로 평가된 집단은 4 번(Node 4)과 9번 (Node 9), 10번(Node 10) 마디를 하나의 가지(branch)로 이루고 있 으며, 그 가지의 깊이는 2이었다. 쓰기 관련 활동을 자주 선택하며

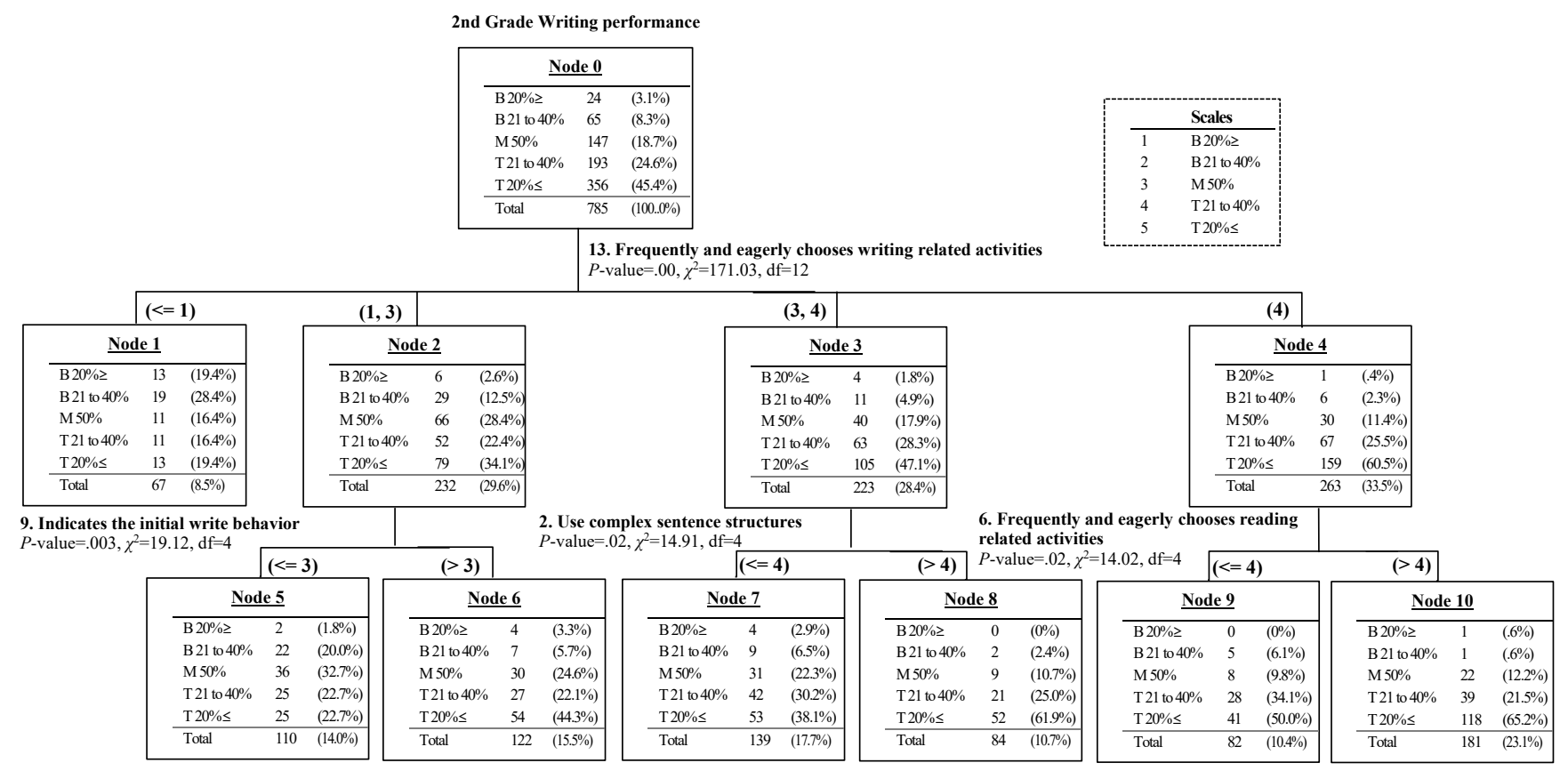

Figure 4. Decision tree model of language \& emergent literacy to predict writing performance in second-year elementary school students. 
어려워하지 않는다는 수준이 '상위 $20 \%$ 이내'로 평가된 아동은 언 어 및 발현 문해능력 문항 6 (읽기 활동을 자주 선택하며 어려워하 지 않는다.) 수준에서 '상위 20\% 이내(181명, 23.1\%)'와 '상위 $20 \%$ 이 하(82명, $10.4 \%)^{\prime}$ 집단으로 구분할수 있었다 $\left(\chi^{2}=14.02, \mathrm{df}=4, p=.02\right)$. 즉, 2 학년 아동의 쓰기 수준은 유치원 시기에 쓰기 관련 활동을 자 주 선택하며 어려워하지 않으며, 읽기 활동을 자주 선택하며 어려 워하지 않는다.'와 같은 언어 및 발현 문해능력에 의해 상위 $20 \%$ 를 예측할수 있는 것으로 나타났다.

간단한 쓰기 관련 활동을 자주 선택하며 어려워하지 않는 수준 이 '중간 $50 \%$-상위 $20 \%$ 이하' 정도인 2학년 집단은 3 번, 7 번, 8 번 마 디를 하나의 가지로 이루고 있었다. 가지의 깊이 2 에서 언어 및 발현 문해능력 문항 2 (다소 복잡한 문장 구조를 사용한다.) 수준이 '상 위 $20 \%$ 이내'와 '상위 $20 \%$ 이하' 집단으로 구분되었다 $\left(\chi^{2}=14.91\right.$, $\mathrm{df}=4, p=.02$ ). 즉, 2 학년 아동의 쓰기 수준은 유치원 시기에 '쓰기 관련 활동을 자주 선택하며 어려워하지 않는 수준이 '중간 $50 \%$-상 위 $20 \%$ 이하'에 포함되는 아동이었다면, 다소 복잡한 문장 구조를 사용할 수 있는 정도가 '상위 $20 \%$ 이상'일 때 초등학교 2학년 쓰기 수준에 차이를 보이는 집단으로 구분될 수 있었다(Figure 4).

그리고 간단한 쓰기 관련 활동을 자주 선택하며 어려워하지 않 는 수준이 ‘하위 $20 \%$-중간 $50 \%$ 이하' 정도인 2학년 집단은 2번, 5 번, 6 번 마디를 하나의 가지로 이루고 있었다. 가지의 깊이 2 에서 언어 및 발현 문해능력 문항 9 (초기 쓰기 행동을 나타낸다.) 수준이 '중 간 $50 \%$ 이내'와 '중간 $50 \%$ 이하' 집단으로 구분되었다 $\left(\chi^{2}=19.12\right.$, $\mathrm{df}=4, p=.003)$. 즉, 2 학년 아동의 쓰기 수준은 유치원 시기에 쓰기 관련 활동을 자주 선택하며 어려워하지 않는다는 부분에 있어 ‘하 위 20\%-중간 $50 \%$ 이하'에 포함되는 아동이었다면, 초기 쓰기 행동 을 나타내는 정도가 ‘중간 50\% 이내’일 때 초등학교 2학년 쓰기 수 준에 차이를 보이는 집단으로 구분될 수 있었다(Figure 4).

Table 10. Prediction rate (accuracy) \& risk of model

\begin{tabular}{|c|c|c|c|c|c|c|c|}
\hline \multirow{2}{*}{\multicolumn{2}{|c|}{ Data }} & \multicolumn{6}{|c|}{ Prediction } \\
\hline & & 1 & 2 & 3 & 4 & 5 & Accuracy (\%) \\
\hline 1 & B 20\% $\geq$ & 0 & 13 & 2 & 0 & 9 & 0 \\
\hline 2 & B 21 to $40 \%$ & 0 & 19 & 22 & 0 & 24 & 29.23 \\
\hline 3 & M 50\% & 0 & 11 & 36 & 0 & 100 & 24.49 \\
\hline 4 & T 21 to $40 \%$ & 0 & 11 & 25 & 0 & 157 & 0 \\
\hline 5 & $\mathrm{~T} 20 \% \leq$ & 0 & 13 & 25 & 0 & 318 & 89.33 \\
\hline \multirow{2}{*}{\multicolumn{2}{|c|}{ A Total (\%) }} & 0 & 8.53 & 14.01 & 0 & 77.45 & 47.52 \\
\hline & & \multicolumn{6}{|c|}{ Risk of model } \\
\hline \multicolumn{2}{|c|}{ Risk estimate } & \multicolumn{6}{|c|}{.525} \\
\hline \multicolumn{2}{|c|}{ SE of risk estimate } & \multicolumn{6}{|c|}{.018} \\
\hline
\end{tabular}

Target variable: Reading performance, Growth method: CHAID.

\section{모형 평가}

2 학년 쓰기 수준에 대한 학령 전 언어 및 발현 문해능력 예측변 수 의사결정나무에 대한 평가는 정확성과 위험도표를 통해 진행하 였다. 전체 예측 정확성은 $47.52 \%$ 였으며, 읽기 수준 상위 $20 \%$ 이내 집단에 대한 언어 및 발현 문해능력의 예측 정확성은 $89.33 \%$ 로 높 았으나 이외 수준의 예측 정확성은 $30 \%$ 미만으로 높지 않았다. 그 리고 예측위험(risk estimate)은 .525 (52.5\%)이었다(Table 10).

\section{논의 및 결론}

이번 연구는 학령 전 ‘언어 및 발현 문해능력'이 초등학교 1, 2학 년 시기의 읽기와 쓰기 학업 수행능력 수준을 예측하는 변수로써 작용하는지를 다섯 가지 연구문제로 구분하여 연구결과를 살펴보 았다. 주요 연구결과에 따라 논의하면 다음과 같다.

첫째, 연구결과 1 에서 6 세 때의 '언어 및 발현 문해능력' 14 문항 과 초등학교 1,2 학년 때의 ‘읽기 및 쓰기 학업 수행능력' 평가 결과 간의 관련성에 대해 상관분석을 통해 살펴보았다. 상관분석 결과 언어 및 발현 문해능력 14 번(컴퓨터를 통해 다양한 활동을 한다)을 제외한 모든 문항들은 유의수준 .001에서 유의한 상관을 보였다. 즉, 연구에 적용된 언어 및 발현 문해능력 평가 문항 모두는 학령 초기 읽기와 쓰기 수행 수준 평가 결과와 관련성이 있는 것을 확인 하였다. 문해능력 발달에 대한 연속성 관점에서 보았을 때 이러한 결과는 유아기 때부터 문해와 관련된 활동을 통해 읽기 쓰기 발달 에 대한 문제를 계속적으로 모니터링 하는 것이 요구된다는 좋은 근거 자료가 된다(Lonigan et al., 2007; Lonigan et al., 2008; Pence, 2007; Whitehurst \& Lonigan, 1998).

둘째, 연구결과 1 에서 읽기 및 쓰기 학업 수행능력은 1학년 읽기 와 쓰기 간에 그리고 2 학년 읽기와 쓰기 간의 상관계수는 .80 이상 으로 매우 높은 것으로 나타났다. 읽기와 쓰기 수행 능력은 서로 밀 접한 관계가 있는 것으로 상호 발달을 한다(Kim, 2017). 그러므로 이번 연구결과는 기본적으로 알고 있는 문해 중재에 대한 좋은 기 본 근거 자료가 될 것으로 보인다.

셋째, 연구결과 1 에서 언어 및 발현 문해능력 14 번 문항(컴퓨터 를 통해 다양한 활동을 한다.)만이 읽기와 쓰기 수행능력 정도와 유의미한 상관관계가 없었다. 단지 컴퓨터를 통해 다양한 활동을 하는 것과 관련 있는 발현 문해능력은 대부분 읽기와 쓰기가 어느 정도 가능한지를 평가하는 문항이었다. 즉, 컴퓨터를 통해 다양한 활동을 하는 유아들은 대부분은 읽기와 쓰기가 가능한 대상자들 인 것으로 보인다. 이러한 결과는 근래 컴퓨터 또는 스마트폰을 이 용하는 아동 연령이 낮아지고 있으며 이러한 효과가 문해능력과 
관련이 있는지를 살펴볼 수 있는 결과이다. 하지만 결과에서 제시 하는 것처럼 컴퓨터를 통해 다양한 활동이 가능한 디지털 문해능 력은 단순히 유튜브를 즐기는 수준의 것을 의미하는 것이 아닌 다 소 복잡한 문장 구조를 이해하고 쓰기 규칙을 어느 정도 이해하여 쓰기 관련 활동을 자주 선택하는 대상자여야 가능하다(Blumberg \& Brooks, 2017).

넷째, 연구결과 2에서 초등학교 1학년 읽기 수준이 상위 $20 \%$ 이 내인 아동은 학령 전 6세 때 간단한 책을 스스로 읽을 수 있으며, 쓰 기 규칙을 어느 정도 이해하고, 몇 가지 행동의 연결된 지시를 따를 수 있었다. 또한 1학년 읽기 수준이 평균 $50 \%$ 이내에 있는 아동은 학령 전 6세 때 간단한 책을 스스로 읽을 수 있으면서 음조가 비슷 한 단어의 운율을 맞출 수 있었다. 이러한 결과는 초등학교를 입학 하기 전 유아기에 의사소통과 관련된 교육은 연결된 지시문을 듣 고 이해하여 행동하기, 그리고 책에 스스로 관심을 갖고 찾아보는 환경과 기본적인 읽기 교육, 운율이 있는 단어가 많이 있는 동시 또 는 동요를 들려주고 표현할 수 있도록 하는 음운인식 활동이 학령 기 읽기 학습 준비에 가장 도움이 되는 활동임을 제시하는 것이다. 그러므로 이러한 활동에 적합한 구체적인 언어 및 문해 목표를 설 정하여 누리과정 교육 현장에 적용하는 것이 효율적인 조기 문해 교육에 바람직할 것으로 보인다(Jung, 2019; Kim, 2017; Kim, 2020; Machado, 2010). 초등학교를 입학하였지만, 문해능력에 제한적 능 력을 보이는 아동을 치료하는 것은 많은 부분에서 학습적인 효율 성이 낮은 것일 수 있다. 그러므로 이러한 읽기와 쓰기에 문제를 보 일 수 있는 아동을 조기 발견하기 위해 유아기 시기 학습 목표에서 부터 문해 환경 요인들을 구체화하는 것이 요구된다(Machado, 2010). 그리고 언어 환경적 요인으로 문해 발달이 저해된 아동들을 위해서도 유아기 문해 학습 환경을 조기에 조성하는 것은 이들 아 동들이 학교 입학 후 읽기장애로 분류되는 것을 조기에 막을 수 있 는 여건이 될 것으로 보인다.

다섯째, 연구결과 3에서 초등학교 1학년 아동 쓰기 수준이 상위 $20 \%$ 이내인 아동은 유치원 시기에 쓰기와 읽기 활동을 자주 선택 하며 어려워하지 않고, “엄마', ‘아빠', ‘너', ‘안녕”과 같은 비교적 간 단한 단어를 기억해서 쓸 수 있었다. 그리고 1학년 쓰기 수준이 평 균 50\% 이내 아동은 유치원 시기에 쓰기 관련 활동을 자주 선택하 며 어려워하지 않으면서, '대한민국', '좋아한다', '웃는다'와 같은 비 교적 복잡한 단어를 기억해서 쓸 수 있고, 음조가 비슷한 단어(운율 맞추기)를 만들 수 있었다. 현재 한글에 대한 읽기와 쓰기 교육이 유치원 과정에서 본격적으로 이루어지는 것은 아니다(Kim, 2020). 학령기에 쓰기 수준이 평균 이상에 포함되어 원활한 학습이 이루 어지기 위해서는 유아기에 단어 쓰기를 할 수 있으면서 운율 맞추
기 활동이 가능할 때이다(Lovelace \& Stewart, 2007; Machado, 2010; Storch \& Whitehurst, 2002). 그러므로 유아기 때부터 필기 도구에 대해 친숙해지고 운율과 장단에 맞추어 말놀이를 할 수 있도록 학 습 목표를 구성하는 것이 이후 학령기 준비에 도움이 될 것으로 보 인다.

여섯째, 연구결과 4 에서 2 학년 읽기 수준이 상위 $20 \%$ 이내인 아 동은 유치원 시기에 간단한 책을 스스로 읽을 수 있으며, 몇 가지 행 동의 연결된 지시를 따를 수 있어야 한다. 이러한 결과를 1학년 때 와 비교하면, 1 학년 때는 읽기 수준이 평균 $50 \%$ 이내 아동은 학령 전 6세 때 간단한 책을 스스로 읽을 수 있으면서 음조가 비슷한 단 어의 운율을 맞출 수 있었지만, 이러한 학령 전 변수가 2 학년 때는 더 이상 읽기능력을 예측하는 변수로 작용하지 않게 되었다. 즉, 초 등학교 2학년 때부터는 운율보다는 스스로 책을 읽을 수 있으면서 몇 가지 연결된 지시를 이해하는 구문 언어능력이 읽기 수준에 더 많은 작용하는 것으로 나타났다(Cabell et al., 2015; Machado, 2010). 즉, 이러한 연구결과를 통해 연령에 적합한 문해 활동이 다를 수 있 음을 제시하는 의미 있는 결과로 해석할 수 있다.

일곱째, 연구결과 5 에서 2 학년 쓰기 수준이 상위 $20 \%$ 이내인 아 동은 유치원 시기에 쓰기와 읽기 활동을 자주 선택하며 어려워하 지 않았다. 그리고 2학년 쓰기 수준이 상위 21-40\% 아동은 쓰기 관 련 활동을 자주 선택하며 어려워하지 않고, 다소 복잡한 문장 구조 로도 표현할 수 있었다. 마지막으로 2학년 쓰기 수준이 평균 50\%인 아동은 쓰기 관련 활동을 자주 선택하며 어려워하지 않고 초기 쓰 기 행동을 나타내는 행동이 나타났다. 2 학년 쓰기 수행 수준은 단 어 쓰기 단계가 지나 문장 쓰기가 원활해야 하는 시기이다. 그러므 로 1학년 때와 비교하였을 때, 단순하건 복잡하건 간에 단어 쓰기 단계에서 벗어나 쓰기 활동에서 복잡한 문장 구조로 표현하는 것 도 가능해야 상위 $40 \%$ 이상의 또래 수준을 유지하며 학습에 도움 을 받을 수 있다. 그리고 또래 평균 이상의 쓰기 능력을 갖기 위해서 는, 쓰기 활동을 자주 선택하면서 어려워하지 않아야 한다. 이러한 조건에 속하기 위해서는 필기도구를 활용하는 것에 대해 어려움이 적어야 한다. 즉, 손가락으로 연필을 잡고 그림을 그리거나 할 때 적 절하게 연필이나 색연필 등을 잡는 법이나 자세에 대한 부분, 어느 정도 연필 잡기에 힘을 주어야 하는지, 그리고 공간을 활용하여 내 용을 적절한 크기로 그리거나 색칠하는 것은 쓰기의 기본기가 된 다(Cabell et al., 2015; Machado, 2010; Parmer \& Bayley, 2007). 이 러한 조건들을 유아기 문해능력 학습 목표로 설정하는 것은 이후 초등학교 때 쓰기 학습이 원활하게 진행될 수 있는 조건이 될 것이 다. 그리고 연령에 맞게 쓰기가 발달하기 위해서는 어느 정도 손으 로 잡고 쓰기가 가능하다면 구문과 어휘 사용에 따라 언어 쓰기능 
력에 있어 차이를 보이게 된다. 그러므로 복잡한 구문을 상황과 맥 락에 맞게 구성하는 언어 표현능력에 대해서는 계속적인 관심을 가져야할 부분이다.

이러한 주요 연구결과를 종합하여, 본 연구가 시사하는 바를 논 의하면 다음과 같다.

초등학교 1-2학년 저학년 시기의 읽기와 쓰기 수행 수준은 유아 기의 책을 스스로 살펴보는 능력과 관심, 쓰기 관련 활동을 자주 선택하고 어려워하지 않는 태도, 음조가 비슷한 단어 운율 맞추기 놀이가 익숙해야 하며, 연결 지시어를 이해하여 행동할 수 있는 언 어 이해능력을 갖추어야 하고, 몇몇 쉬운 단어 또는 어려운 단어도 쓸 수 있는 문해 환경이 주어져야 한다. 그리고 복잡한 문장 구조도 이해하고 표현할 수 있는 언어능력을 갖추는 것은 읽기와 쓰기와 깊은 관련이 있는 것으로 나타났다. 이러한 연구결과들은 해외의 발현 문해능력과 읽기 및 쓰기와의 관계를 살펴본 선행연구들과 어느 정도 일치하는 부분이다(Lonigan et al., 2007; Lonigan et al., 2008; Pence, 2007; Whitehurst \& Lonigan, 1998). 하지만 이번 연구 를 통해 한국어와 한글을 사용하는 유아 또는 초등학생들에게도 발현 문해능력과 읽기 및 쓰기와의 관계를 살펴보았다는 것은 큰 의미가 있다.

특히 유아기에 갖추어야 할 문해 관련 능력 또는 학령 초기 읽기 와 쓰기 학습 발달을 면밀하게 살펴보아야 하는 언어재활사, 유아 교사는 이번 연구결과를 통해 발현 문해능력과 언어와의 관련성을 확인하는 계기가 되었을 것이다(Bean, Perez, Dynia, Kaderavek, \& Justice, 2020; Je, 2014; Park, 2018).

초등학교 입학 이후의 읽기와 쓰기 수준에 대한 향상을 위해서 는, 유아기에 단지 의사소통 능력 향상을 목표로 발현 문해능력 향 상 환경을 조성하는 현재의 누리과정 의사소통 목표에서 더 나아 가 구체적인 의사소통 지도 목표안이 설정되어 있어야 한다. 그리고 유아 읽기 교육에 있어 낱말 읽기 환경을 조성하고는 있지만, 통글 자 낱말을 반복적으로 제시하는 수준의 총체적 언어 교육법 중심 의 읽기 교육보다는 한글의 특성을 고려한 발음 중심의 읽기 교수 가 더 효과적일 수 있다(Kim, 2017). 즉, 발음 중심의 읽기 교수와 음운인식 훈련을 통해 한글 파닉스 교육법이 유아 교육과정에 제 시된다면 유아들을 조금 더 확실하게 읽기와 쓰기에 대한 기본기 수준을 갖출 수 있을 것으로 보인다.

PSKC 데이터 분석을 통해 학령 초기의 읽기와 쓰기 수행 수준 은 학령전기 발현 문해능력의 어떠한 내용과 주로 관련이 있는지를 살펴보았다. 이러한 연구 분석 결과는 국내 문해력 향상을 위해, 현 누리과정 교육에서 어떠한 부분의 발현 문해능력에 더 집중적인 교육이 주어져야 하는지를 제시하는 중요한 기초자료가 될 것으로
보인다. 또한 다양한 발현 문해능력 하위 영역 중 한글 문해능력과 주로 관련된 발현 문해능력에 대한 이해를 통해 누리과정 의사소 통 읽기와 쓰기 하위 영역 목표 구체화에 도움이 되는 기초 자료가 될 것이다.

이번 연구결과에서 확인한 연구결과를 토대로 본 연구가 갖는 제한점을 밝히며 후속연구에 대한 제언을 제시하면 다음과 같다. 첫째, 이번 연구결과는 아동의 연령에 맞는 읽기와 쓰기 발달을 살 펴본 종단연구라는 이점이 있었지만 실험조건과 같은 상황변수 통 제가 어려운 조건에서 평가가 이루어졌다. 이에 이후 실험연구를 통 해 본 연구의 결과를 비교해 보는 것은 의미가 있을 것이다. 둘째, 이 번 연구에서 예측변수로 작용한 언어 및 발현 문해능력 14 개 변수 와 읽기와 쓰기 수행 수준 목적변수 4 가지는 모두 유아교사와 초등 학교 담임교사가 주관적으로 개인의 관점에서 아동의 능력을 5점 척도로 평가한 것들이었다. 하지만 이러한 주관적 평가방법은 신뢰 도의 문제를 가지고 있다. 이에 다음 연구에서는 타당화가 진행된 평가도구를 활용하여 대상자들의 언어 및 발현 문해능력과 읽기 및 쓰기 수행 수준을 평가하는 것이 요구된다.

\section{REFERENCES}

Bean, A. F., Perez, B. I., Dynia, J. M., Kaderavek, J. N., \& Justice, L. M. (2020). Book reading engagement in children with autism and language impairment: associations with emergent literacy skills. Journal of Autism and Developmental Disorders, 50(3), 1018-1030.

Blumberg, F. C., \& Brooks, P. J. (2017). Cognitive development in digital contexts. London: Academic press.

Cabell, S. Q., Justice, L. M., Kaderavek, J. N., Turnbull, K. P., Breit-Smith, A., \& Fazal, Z. (2015). Emergent literacy: lessons for success. San Diego: Plural Publishing.

Catts, H. W., Adlof, S. M., \& Weismer, S. E. (2006). Language deficits in poor comprehenders: a case for the Simple View of Reading. Journal of Speech Language and Hearing Research, 49(2), 278-293.

Choi, N. Y. (2007). The effect of consonant recognition, phonetic recognition, and processing power on children's reading of Korean words (Doctoral dissertation). Seoul National University, Seoul, Korea.

Cunningham, A. E., \& Stanovich, K. E. (1997). Early reading acquisition and its relation to reading experience and ability 10 years later. Developmental Psychology, 33(6), 934-945.

Ehri, L. C. (2005). Learning to read words: theory, findings, and issues. Scientific Studies of Reading, 9(2), 167-188. 
Ehri, L. C., \& Wilce, L. S. (1985). Movement into reading: is the first stage of printed word learning visual or phonetic?. Reading Research Quarterly, 20(2), 163-179.

Gough, P. B., Hoover, W. A., \& Perterson, C. L. (1996). Some observation on a simple of view of reading. In C. Cornaldi \& J. Oakhill (Eds). Reading comprehension difficulties: process and intervention (pp.1-13). Mahwah, NJ: Lawrence Erlbaum Associates.

Jang, Y. A. (2014). Nursery teacher awareness of reading and writing education (Master's thesis). Dongui University, Busan, Korea.

Je, H. (2014). Effect of emergent literacy skills on monosyllable reading of children with typical development and mild intellectual disability (Doctoral dissertation). Ewha Womans University, Seoul, Korea.

Jung, K. H. (2019). Developmental characteristics of spelling ability of kindergarten to 3rd grade children. Communication Sciences \& Disorders, 24(1), 19-30.

Kass, G. V. (1980). An exploratory technique for investigating large quantities of categorical data. Journal of the Royal Statistical Society: Series C (Applied Statistics), 29(2), 119-127.

Kim, J. H. (2020). Analysis of connection in the national language curricula between kindergarten and elementary school: with a focus on the communication domain for Nuri curriculum for 5-year-old and the national elementary school curriculum for 1st-2nd graders under the revised curriculum of 2015. Journal of Learner-Centered Curriculum and Instruction, 20(1), 587-605.

Kim, S. A. (2005). Analysis of the needs of kindergarten teachers for reading and writing guidance of 5-year-old infants (Master's thesis). Chungnam National University, Daejeon, Korea.

Kim, S. H., \& Kim, H. Y. (2016). The current state and teachers' perceptions of reading and writing education at kindergartens. The Journal of Korean Teacher Education, 33(1), 161-190.

Kim, Y. S. (2017). Systematic and precise instruction of reading and writing. Seoul: Hakjisa.

Lee, E. J., \& Oh, S. J. (2019). Association between pragmatic language competence and emotional/behavioral outcomes of 3rd graders in elemental school. Communication Sciences \& Disorders, 24(4), 906-924.

Lee, E. J. (2020). Data mining decision tree models of multicultural acceptability of multicultural adolescents in Korea: focusing on ability of language skills (listening, speaking, reading, writing) of Korean and mother's native languages. Communication Sciences \& Disorders, 25(2), 299-317.

Lee, H. J. (2005). The perception of kindergarten and first grade teachers about reading \& writing education for early childhood (Master's thesis). Ewha Womans University, Seoul, Korea.

Lee, M. J. (2004). Early literacy education according to the features of Hangul. Journal of Future Early Childhood Education, 11(1), 169-192.

Lee, S. H. (2008). The effect of developing and applying balanced infant reading programs (Master's thesis). Dongduk Women's University, Seoul, Korea.

Lim, K., \& Son, E. Y. (2018). Effects of book-making activity of literacy teaching methods on preschooler's English literacy development and learning motivation. Journal of Learner-Centered Curriculum and Instruction, 18(12), 885-907.

Lonigan, C. J. (2006). Development, assessment, and promotion of preliteracy skills. Early Education and Development, 17(1), 91-114.

Lonigan, C. J., Burgess, S. R., \& Anthony, J. L. (2000). Development of emergent literacy and early reading skills in preschool children: evidence from a latent-variable longitudinal study. Developmental Psychology, 36(5), 596613.

Lonigan, C. J., Schatschneider, C., Westberg, L., \& The National Early Literacy Panel (NELP). (2008). Identification of children's skills and abilities linked to later outcomes in reading, writing, and spelling. In The National Early Literacy Panel (Ed.), Developing early literacy (pp. 55-106). Jessup, MD: National Institute for Literacy.

Lonigan, C. J., Wagner, R. K., \& Torgesen, J. K. (2007). Examiner's manual. Test of Preschool Early Literacy (TOPEL). Austin, TX: Pro-ed.

Lovelace, S., \& Stewart, S. R. (2007). Increasing print awareness in preschoolers with language impairment using non-evocative print referencing. Language, Speech, and Hearing Services in Schools, 38(1), 16-30.

Machado, J. M. (2010). Early childhood experiences in language arts: early literacy (9th Ed.). Belmont, CA: Wadsworth Cengage Learning.

Ministry of Education. (2019). Education Department Notice No. 2019-1899. Seoul: MOE of the Republic of Korea.

National Early Literacy Panel (NELP). (2004). The National Early Literacy Panel: a research synthesis on early literacy development. Presentation to the Annual Meeting of the National Association of Early Childhood Specialists, Anaheim, CA.

NICHD Study of Early Child Care and Youth Development: Phase II, 19951999 [United States] (ICPSR 21941). 21941-Questionnaire-questionaires. Retrived from http://www.icpsr.umich.edu/icpsr-web/ICPSR/studies/21941 Park, E. H., Kim, J. H., \& Park, S. H. (2013). A study of comparison between teacher's expectation level and actual teaching level of children's reading and writing by age. Early Childhood Education Research \& Review, 17(5), 
465-487.

Park, E. H., Lee, J. H., \& Jeon, H. J. (2012). Meanings of literacy curriculum as perceived by early childhood teachers. Journal of Children Literature and Education, 13(2), 25-45.

Park, N. (2018). The effect of the Nuri curriculum-based dialogic reading intervention on the word reading and comprehension of children with disabilities. The Korean Journal of Early Childhood Special Education, 18(2), 27-54.

Parmer, S., \& Bayley, R. (2007). Foundation of literacy: a balanced approach to language, listening and literacy skills in the early years. London: Continuum International Publishing group.

Pence, K. L. (2007). Assessment in emergent literacy. San Diego: Plural Pub. Storch, S. A., \& Whitehurst, G. J. (2002). Oral language and code-related pre- cursors to reading: evidence from a longitudinal structural model. Developmental Psychology, 38(6), 934-947.

van Kleeck, A. (1990). Emergent literacy: learning about print before learning to read. Topics in Language Disorders, 10(2), 25-45.

Whitehurst, G. J., \& Lonigan, C. J. (1998). Child development and emergent literacy. Child Development, 69(3), 848-872.

Won, S., Won, H., Jang, W., Lee, J., \& Pae, S. (2020). Predicting word reading and word writing of kindergarteners with phonology, orthography, morpho-semantics. Communication Sciences \& Disorders, 25(3), 517-530.

Yang, M., Kim, B., \& Ra, J. (2017). Predicting word reading and spelling in first graders with dyslexia. Communication Sciences \& Disorders, 22(4), 690704. 
Appendix 1. Academic skills: Language and literacy

\begin{tabular}{|c|c|c|c|c|c|c|}
\hline \multicolumn{2}{|c|}{ 다음의 각 문장에 대해 학생이 동의하는 정도에 동그라미( $\bigcirc)$ 하여 주십시오. } & \multirow{2}{*}{$\begin{array}{l}\text { 아직 하지 } \\
\text { 않음 } \\
1\end{array}$} & \multirow{2}{*}{$\begin{array}{l}\begin{array}{c}\text { 하기 } \\
\text { 시작함 }\end{array} \\
\text { (2) }\end{array}$} & \multirow{2}{*}{$\begin{array}{c}\begin{array}{c}\text { 어느 정도 } \\
\text { 해냄 }\end{array} \\
\text { (3) }\end{array}$} & \multirow{2}{*}{$\begin{array}{l}\text { 잘하는 } \\
\text { 편임 } \\
\text { (4) }\end{array}$} & \multirow{2}{*}{$\begin{array}{c}\text { 능숙함 } \\
\text { (5) }\end{array}$} \\
\hline $\begin{array}{l}\text { 언어 및 } \\
\text { 읽기 }\end{array}$ & $\begin{array}{l}\text { 1. 몇 가지 행동의 연결된 지시를 따를 수 있다. } \\
\text { 예) 이 크레파스를 가지고 자신이 좋아하는 동물을 그리세요. 그리고 크레파스는 노란 } \\
\text { 색 통에 정리하고, 그린 그림은 이야기나누기 시간에 친구들에게 보여주세요. }\end{array}$ & & & & & \\
\hline & $\begin{array}{l}\text { 2. 다소 복잡한 문장 구조를 사용한다. } \\
\text { 예) ‘ㅇㄱㅏ 우산을 가져왔더라면, 비를 맞지 않았을 텐데' '우리 1학년 올라가자마자 } \\
\text { 현장 학습 갈 수 있겠지?’와 같은 말을 한다. }\end{array}$ & (1) & (2) & (3) & (4) & (5) \\
\hline & $\begin{array}{l}\text { 3. 누군가 읽어준 글이나 이야기를 이해하고 해석한다. } \\
\text { 예) 들려준 이야기를 다시 말하거나, 이야기가 왜 그렇게 끝났는지 설명하거나, 이야 } \\
\text { 기의 일부를 자신의 상황과 연결 지을 수 있다. }\end{array}$ & (1) & (2) & (3) & (4) & (5) \\
\hline & 4. 한글의 모든 자음과 모음을 쉽고 빠르게 말할 수 있다. & (1) & (2) & (3) & (4) & (5) \\
\hline & $\begin{array}{l}\text { 5. 음조가 비슷한 단어(운율 맞추기)를 만들 수 있다. } \\
\text { 예) '리'자로 끝나는 말(개나리, 오리, 유리, 항아리)을 말할 수 있다. }\end{array}$ & (1) & (2) & (3) & (4) & (5) \\
\hline & $\begin{array}{l}\text { 6. 읽기 활동을 자주 선택하며 어려워하지 않는다. } \\
\text { 예) 친숙한 책을 반복해서 읽거나, 교실에서의 책 읽기 활동을 자주 선택하거나, 도서 } \\
\text { 관에 가자고 한다. }\end{array}$ & (1) & (2) & (3) & (4) & (5) \\
\hline & 7. 줄거리의 단서나 그림을 보고 그다음에 어떤 이야기가 이어질 것인지 예측할 수 있다. & (1) & (2) & (3) & (4) & (5) \\
\hline & $\begin{array}{l}\text { 8. 간단한 책을 스스로 읽는다. } \\
\text { 예) 언어의 패턴이 반복되는 책을 읽는다. }\end{array}$ & (1) & (2) & (3) & (4) & (5) \\
\hline \multirow[t]{5}{*}{ 쓰기 } & $\begin{array}{l}\text { 9. 초기 쓰기 행동을 나타낸다. } \\
\text { 예) 단어를 적기 위해 서두의 자음을 사용하거나(과자 } \rightarrow \text { ᄀ), 소리를 표현하기 위해 철 } \\
\text { 자를 그대로 적거나(미음 } \longrightarrow \text { ㅁ), 말과 생각을 전달하기 위해 발음 나는 대로 적는다 } \\
\text { (닭 } \rightarrow \text { 닥, 갔 다 } \rightarrow \text { 가따). }\end{array}$ & (1) & (2) & (3) & (4) & (5) \\
\hline & 10. '엄마', '아빠', '너', '안녕’과 같은 비교적 간단한 단어를 기억해서 쓴다. & (1) & (2) & (3) & (4) & (5) \\
\hline & 11. '대한민국', '좋아한다', '웃는다’와 같은 비교적 복잡한 단어를 기억해서 쓴다. & (1) & (2) & (3) & (4) & (5) \\
\hline & $\begin{array}{l}\text { 12. 쓰기 규칙을 어느 정도 이해하고 있는 것 같다. } \\
\text { 예) 단어 간 띄어쓰기를 하고 문장 끝에 마침표를 찍는다. }\end{array}$ & (1) & (2) & (3) & (4) & (5) \\
\hline & $\begin{array}{l}\text { 13. 쓰기 관련 활동을 자주 선택하며 어려워하지 않는다. } \\
\text { 예) 자유선택활동시간에 쓰기 활동을 자주 선택하거나, 활동 및 놀이를 위해 기호를 } \\
\text { 표시하거나 메모를 한다. }\end{array}$ & (1) & (2) & (3) & (4) & (5) \\
\hline $\begin{array}{l}\text { 디지털 } \\
\text { 리터러시 }\end{array}$ & $\begin{array}{l}\text { 14. 컴퓨터를 통해 다양한 활동을 한다. } \\
\text { 예) 그림을 그리거나, 물건을 세거나, 숫자, 글자, 단어를 타이핑한다. }\end{array}$ & (1) & (2) & (3) & (4) & (5) \\
\hline
\end{tabular}

Source: KICCE (Korea Institute of Child Care and Education, https://kicce.re.kr/panel). 


\section{국문초록}

\section{학령전 ‘언어 및 발현 문해능력'과 초등학교 1,2 학년 문해력 수준 간의 관계: 데이터 마이닝 의사결정나무모형 분석 이은주 \\ 이화여자대학교 특수교육연구소}

배경 및 목적: 본 연구는 초등학교 1-2학년 시기에 한글 읽기와쓰기 능력 성취 수준에 영향을 미치는 학령전 발현 문해능력과 언어 이 해 요소들을 살펴보고, 언어치료 및 유아교육 현장에서 어떠한 언어 및 발현 문해능력에 대한 명시적인 교수가 요구되는지를 살펴보았 다. 방법: 한국육아정책연구소(Korea Institute of Child Care and Education, KICCE) 한국아동패널(Panel Study on Korean Children, PSKC)의 2014년 7차 데이터(유치원생, 6세)와 2015년 8차(초등학교 1학년, 7세), 2016년 9차(초등학교 2학년, 8세) 데이터를 이용하여 의사결정나무모형 분석을 실시하였다. 결과: 초등학교 1-2학년 저학년 시기의 읽기와 쓰기 수행 수준이 또래 평균 $20 \%$ 이상 아동들은 학령전에 ‘책에 관심을 가지고 스스로 읽는 능력, '쓰기 관련 활동을 자주 선택하고 어려워하지 않는 태도', '단어 운율 맞추기 놀이를 능 숙하게 할 수 있으며', ‘연결 지시어를 이해하고 지시에 따라 행동할 수 있고', ‘몇몇 쉬운 단어 또는 어려운 단어도 쓸 수 있는 문해능력'을 갖추고 있었다. 논의 및 결론: 이번 연구결과는 읽기 및 쓰기 수행 수준이 낮은 대상자들에게는 어떠한 부분의 문해능력에 더 집중적인 언어치료 및 누리과정 교육이 주어져야 하는지를 제시하는 기초자료가 될 것으로 보인다.

핵심어: 한국아동패널(PSKC), 의사결정나무모형, 발현 문해능력, 읽기, 쓰기

이 논문은 2021년 대한민국 교육부와한국연구재단의 지원을 받아 수행된 연구임(No. NRF-2020S1A5B5A16082517).

\section{참고문헌}

교육부 (2019). 교육부 고시 제2019-189호. 서울: 교육부.

김선아 (2005). 만 5세 유아의 읽기, 쓰기 지도에 대한 유치원 교사의 요구분석. 충남대학교 교육대학원 석사학위논문.

김순환, 김희영 (2016). 유치원에서의 읽기, 쓰기 교육 실태 및 교사 인식. 한국교원교육연구, 33(1), 161-190.

김영순 (2017). 찬찬히체계적· 과학적으로 배우는 읽기 \& 쓰기 교육. 서울: 학지사.

김정희 (2020). 유-초 언어 교육과정의 연계 분석: 5세 누리과정 의사소통영역과 2015 개정 초등교육과정 1-2학년군 언어교육을 중심으로. 학습자중 심교과교육연구, 20(1), 587-605.

박나리 (2018). 누리과정 기반의 대화식 책 읽기 활동이 장애 유아의 단어 읽기 능력과 이해력에 미치는 영향. 유아특수교육연구, 18(2), 27-54.

박은혜, 김정효, 박선혜 (2013). 유아 연령별 읽기, 쓰기에 대한 교사의 기대수준과 실제수준 비교. 유아교육학논집, 17(5), 465-487.

박은혜, 이지현, 전홍주 (2012). 유아교사가 인식하는 문해 교육과정의 의미. 어린이 문학교육 연구, 13(2), 25-45.

양민화, 김보재, 나종민 (2017). 초등학교 1학년 난독증 아동의 단어읽기 및 철자능력 예측지표 연구. Communication Sciences \& Disorders, 22(4), 690-704.

원은상, 원효은, 장우정, 이정민, 배소영 (2020). 취학전 아동의 낱말 읽기 및 낱말 쓰기 설명요인: 음운처리력, 철자력, 형태의미력을 중심으로. Com-

munication Sciences \& Disorders, 25(3), 517-530.

이문정 (2004). 한글의 문자 특성에 적합한 유아 읽기, 쓰기 교육. 미래유아교육학회지, 11(1), 169-192.

이은주, 오소정 (2019). 화용언어능력과 정서/행동문제와의 관련성-초등학교 3학년 아동을 중심으로. Communication Sciences \& Disorders,

24(4), 906-924.

이은주 (2020). 다문화청소년의 다문화 수용성 예측요인에 대한 데이터 마이닝 의사결정나무모형 분석: 한국어와 어머니 모국어에 대한 4 가지 언어

사용 능력(듣기, 말하기, 읽기, 쓰기)을 중심으로. Communication Sciences \& Disorders, 25(2), 299-317.

이숙희 (2008). 균형적 유아 읽기 프로그램의 개발 및 적용 효과. 동덕여자대학교 대학원 석사학위논문. 
이혜진 (2005). 유아기 읽기, 쓰기 교육에 대한 유치원 교사와 초등학교 1학년 교사의 인식. 이화여자대학교 교육대학원 석사학위논문.

임경수, 손은령 (2018). 문해 교수방법에 따른 책 만들기 활동이 유아의 영어 문해 발달과 학습동기에 미치는 효과. 학습자중심교과교육연구, 18(12), 885-907.

장영애 (2014). 읽기와쓰기 교육에 관한 어린이집 교사의 인식. 동의대학교 대학원 석사학위논문.

정경희 (2019). 유치원에서 초등 3학년 아동의 철자쓰기 발달 특성. Communication Sciences \& Disorders, 24(1), 19-30.

제현순 (2014). 초기 문해능력 기술들이 일반아동 및 지적장애아동의 1음절읽기 능력에 미치는 영향. 이화여자대학교 일반대학원 언어병리학 박사학 위논문.

최나야 (2007). 자모 인식, 음운인식론적 인식 및 처리능력이 유아의 한글 단어 읽기에 미치는 영향. 서울대학교 대학원 박사학위논문.

\section{ORCID}

이은주(제1저자, 교신저자, 연구교수 https://orcid.org/0000-0003-2976-3151) 